NBER WORKING PAPER SERIES

\title{
SECURITIES ACTIVITIES OF U.S. COMMERCIAL \\ BANK AFFILIATES: LESSONS FROM \\ THE INTERNATIONAL FINANCIAL MARKETS
}

Richard M. Levich

Working Paper No. 1428

NATIONAL BUREAU OF ECONOMIC RESEARCH

1050 Massachusetts Avenue

Cambridge, MA 02138

August 1984

This chapter was written while the author was a visiting Fellow at Centre d'Enseignement Superieur des Affaires (Jouy-en-Josas, France) and the Australian Graduate School of Management (Sydney, Australia). The author is grateful to William Dudley, Sheppard Poor, Arthur Stonehill, and Ingo Walter for helpful comments on earlier drafts and to Fabian von Hofe and Tony Mayer for background discussions and data on the Euro-bond market. The author acknowledges responsibility for any errors that remain. The research reported here is part of the NBER's research program in International Studies and project Productivity. (World Economy). Any opinions expressed are those of the author and not those of the National Bureau of Economic Research. 
NBER Working Paper \#1428

August 1984

\section{Securities Activities of U.S. Commercial Bank Affiliates: Lessons From the International Financial Markets}

\section{AB S TRACT}

An issue confronting U.S. policymakers is whether restrictions on securities activities of U.S. commercial banks ought to be abolished within a broader program of banking and financial market deregulation. The Euro-bond market offers an opportunity to examine the performance of a largely unregulated securities market and the behavior of U.S. commercial bank affiliates within that market. In this paper, we present evidence on the development and performance of the Euro-bond market over the last 20 years and then infer the likely consequences if a similar level of deregulation and competition were permitted in the United states.

Data on the level of competition is presented along with an analysis of underwriting strategies and innovations that have been pursued in the market. The most serious criticisms concerning Euro-bond market operations--e.g. excessive spreads, conflicts of interest, and the Grey market--are reviewed.

Overall, the evidence suggests that the Euro-bond market has experienced dynamic and vigorous growth, resulting in net benefits to both borrowers and lenders without exposing the financial instituitons to significant risks. Large U.S. companies regularly tap the Euro-bond market and capture some of these benefits. Allowing U.S. commercial bank affiliates to compete in the U.S. securities markets could make these benefits more certain and expand their availability to all firms with a minimal increase in risk to the safety and soundness of the banking system.

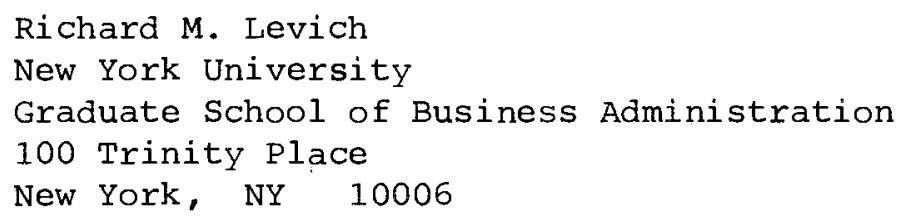


I. Introduction

A major question facing U.S. policymakers today is whether ex isting restrictions on securities acitivities of U.S. commercial banks ought to be abolished as part of a broader program of banking and financial market deregulation, or whether policymakers should preserve the status quo. In the discusion of this issue, two points are often forgotten:

(a) An essentially unregulated securities market, the Euro-bond market, has existed for over 20 years, and

(b) U.S. commercial bank affil iates have been important participants in the Euro-bond market and -- where they are permitted to do so -- in foreign securities markets as wel1. 1

This historical experience suggests that it may be appropriate to examine the behavior of international capital markets, and to ascerta in what lessons, if any, they hold for financial deregulation in the United States.

The purpose of this paper is to offer a contribution to the debate on deregulation of investment banking activities by drawing on the experience in international capital markets. The evidence we present addresses two broad sets of issues: 
(1) Is it possible for private agents to organize the underwriting of securities, issuing and dealing functions in an efficient manner without restricting competitive forces?

(2) Does the presence of agents (i.e. commercial banks) who engage in related financial transactions (e.g. accepting deposits, lending, managing trust funds, etc.) have any adverse effects on the underwriting and issuing markets, on related financial transactions (e.g. unbiased credit evaluations) or on the basic safety and soundness of the banking system ?

One major segment of the international capital market, the Euro-bond market, is our laboratory for exploring question one. The Euro-bond market, a) though not entirely free of regulation, operates under substantially fewer restrictions than those placed on domestic and foreign bond issues. In particular, there are no regulatory restrictions on firms wishing to engage in underwriting or dealing activities. Only economic factors-adequate financial capital, human capital and appropriate technology--make it costly for firms to enter (or leave) the Euro-bond market.

The Euro-bond market may thus be studied as an example of how well the underwriting and issuing functions of a primary market are performed in an environment that is largely unregulated and open to competitive forces. Certain characteristics of the market--the concentration of underwriters, the allegiance of issuers to underwriters, the cost of underwriting services, and the cost of funds to issuers--might be taken as a standard of comparison against other markets. 
In addressing the second question, the Euro-bond market again offers a potentially useful source of evidence. Major foreign banks and offshore subsidiaries of U.S. bank holding companies compete head-to-head with more specialized investment banking or issuing houses. It will generally be the case that the major foreign and U.S. commercial banks will offer related financial services to corporate issuers and a fiduciary responsibility toward other bank customers. Consequently, these banks may be thought to be more exposed to problems of conflict of interest and abuse of fiduciary trust than may be the case with more specialized issuing houses. The record of the Euro-bond market is open to examination in this regard.

The second question might also be approached in another manner, by analyzing the primary issue markets in countries other than the United States. In many industrial countries commercial banking and investment banking are not formally separated, and commercial banks are not prohibited from underwriting corporate securities, including equities. These foreign market settings offer another opportunity to analyze whether the combination of commercial and investment banking within one financial institution allows for a smoothly functioning primary issue market in which potential conflict of interest problems are manageable and public confidence in the safety and soundness of banks is maintained. ${ }^{3}$

However, because of the great differences in macroeconomic policies, fiscal incentives and the institutional environment, we will argue that the experience with combined commercial and investment banking outside the United States is less relevant for our study. Indeed it will be argued that the thrust of regulation itself is fundamentally different in other industrial countries than in the United States. 4 
Consequently, we propose to focus on the Euro-bond market as an arena in which both of our above research questions can be addressed. The Euro-bond market is, first, an example of a largely unregulated market and second, a market in which institutions take on underwriting and investment banking duties in addition to the ir commercial banking functions. We propose that the analysis of the Euro-bond market, in general, and the role played by banking institutions, in particular, is directly relevant for assessing the implications of expanding competition in the United States by allowing separately capitalized securities affiliates of commercial banks to engage in investment banking activities.

Our methodolgy is not that of formal hypothesis testing. Rather, we cla im that the Euro-bond market and the U.S. corporate securities markets are comparable in the sense that our findings concerning the degree of ti competion or advantages to borrowers and lenders might apply equaliy to

U.S. securities markets were the Glass-Steagall act abolished. Our approach, therefore, is to appraise the overall development and success of the Euro-bond market with its attendant problems and risks. We then attempt to infer what lessons there are in this experience for deregulation of U.S. financial markets.

The evidence presented in this paper suggests that the Euro-bond market has indeed "succeeded" in the sense that the market can survive without artificial support and continues to fulfill the very real demands of both borrowers and lenders. In the early years, the market enjoyed "protection" because of U.S. policies that pushed borrowers offshore. Still, fixed income securities underwriting could hardly be labelled risk-free in the post-Bretton Woods decade. Demand for Euro-bond issues fluctuated with both exchange rate and interest rate expectations. To protect their 
interests while developing the market, underwriters adopted a variety of protective measures -- e.g. dealing with AAA clients to minimize credit risks; establishing large syndicates to spread underwriting risks; setting transaction costs high enough to provide an adequate cushion; and establishing "grey markets" to minimize the price risk of unsold securities."

In addition, our analysis suggests that if the United States allows commercial banking and investment banking activities to take place withing the context of a single bank holding company, the result will not be a system of "universal banks" that resembles those existing in Europe. This is because the concentration in the banking industry is, and is likely to remain, far less in the United States than in Europe, the linkages between corporations and banks are weaker in the Unites States than in Europe, and the thrust of regulation is vastly dissimilar. Furthermore, if the U.S. commercial banks were permited to engage in investment banking activities, they would do so within the framework of regulations to establish minimum capital requirements for the new banking activities, and to insure adequate separation of personnel and organization between commercial and investment banking activities. 'As a result, only a minority of the nation's 14,000 commercial banks would qualify to establish investment banking operations.

Evidience from the Euro-bond market strongly suggests that, within its essentially unregulated environment with no artificial barriers to entry, underwriters have indeed behaved prudently. They organized a market, allowing substantial benefits to both borrowers and lenders, without incurring substantial risks. The evidence offers strong reason to believe that U.S. commercial bank holding companies could likewise behave prudently in competition with U.S. investment banking houses without undermining the 
basic safety and soundness of the system. Regulation and supervision of commercial bank-related corporate securities underwriting and dealing activities would establish minimum capital requirements, adequate disclosure of information, and sufficient separation from commercial banking operations. The increased competition would in all 1iklihood result in significant net benefits to the economy at a minimal increase in risk to society.

The plan for the paper is as follows. In Section II, we present background information on the Euro-bond market. The evidence clearly shows that the Euro-bond market is a major financial market offering a variety of advantages over domestic markets for both borrowers and lenders. An appraisal of the underwriting stategies and competitive characteristics in the Euro-bond market is offered in Section III. The evidence presented here on industry concentration and switching among lead managers suggests greater competition in the Euro-bond market than in U.S. corporate underwriting. In Section IV, we identify some of the problems and risks that have been associated with Euro-bond market operations and review some of the corrective steps and innovations that have taken place to deal with them. The scope for transplanting the spirit of Euro-bond market competition is explored in Section V. A summary and conclusions follow in Section VI. 


\section{Background Information on the Euro-bond Market}

The purpose of this section is to describe the important operating characteristics of the Euro-bond market, and to present a variety of statistical data indicating the size and scope of the market. We intend to show that the Euro-bond market is indeed a major financial market, and that our later findings concerning the behavior of underwriters and investment bankers in this market may be indicative of behavior in other major markets such as the United States, were it to allow securities affiliates of commercial banks to compete in the financial services industry.

Citing World Bank records, Mendelsohn (1980, p.137) reports that the first Euro-bond was issued in 1957 for Petrofina S.A., the Belgian petroleum company. The issue was denominated in U.S. dollars in the amount of $\$ 5,000,000$. In 1982 , the total of new Euro-bond issues surpassed $\$ 50$ billion. Individual 
issues have sometimes exceeded $\$ 500$ million. ${ }^{10}$ By comparison, total bond issues in the United States by private institutions totalled $\$ 53.4$ billion in 1982. Public government issuesraised another $\$ 324.9$ billion. 11

The Petrofina issue illustrates the two key features of a Euro-bond. A Euro-bond is (1) underwritten by an international syndicate, and (2) offered for sale simultaneously in a number of countries. As a consequence of (2), the issue is usually denominated in a currency (or unit of account) that is foreign to a large number of the buyers. Niendelsohn (1983, pp. 4-5) points out that with the introduction of the "bought deal", in which a single underwriter commits to an entire issue in advance, the first of these dimensions of a Euro-bond may be lost as a distinctive feature of Euro-bond issues.

In contrast, a foreign bond is an obligation of a foreign company that is underwritten by a syndicate of domestic banks, denominated in domestic currency and offered for sale in the domestic market. Examples of foreign bonds are Yankee bonds, dollar obligations of non-U.S. firms underwritten and issued in the United States, and Samurai bonds, yen obligations of non-Japanese firms underwritten and issued in Japan.

Table 1 presents data on the yearly flow of international bond issues. On average, the share of Euro-bonds and foreign bonds in the market is roughly equal. The average annual growth rate of Euro-bond issues over the period 1970-1981 was 22\%. Wiany of the important characteristics of the various bond issues are displayed for comparison in Table 2 . 
$-10-$

Table 1

INTERNAT IONAL BOND ISSUES, 1970-1981

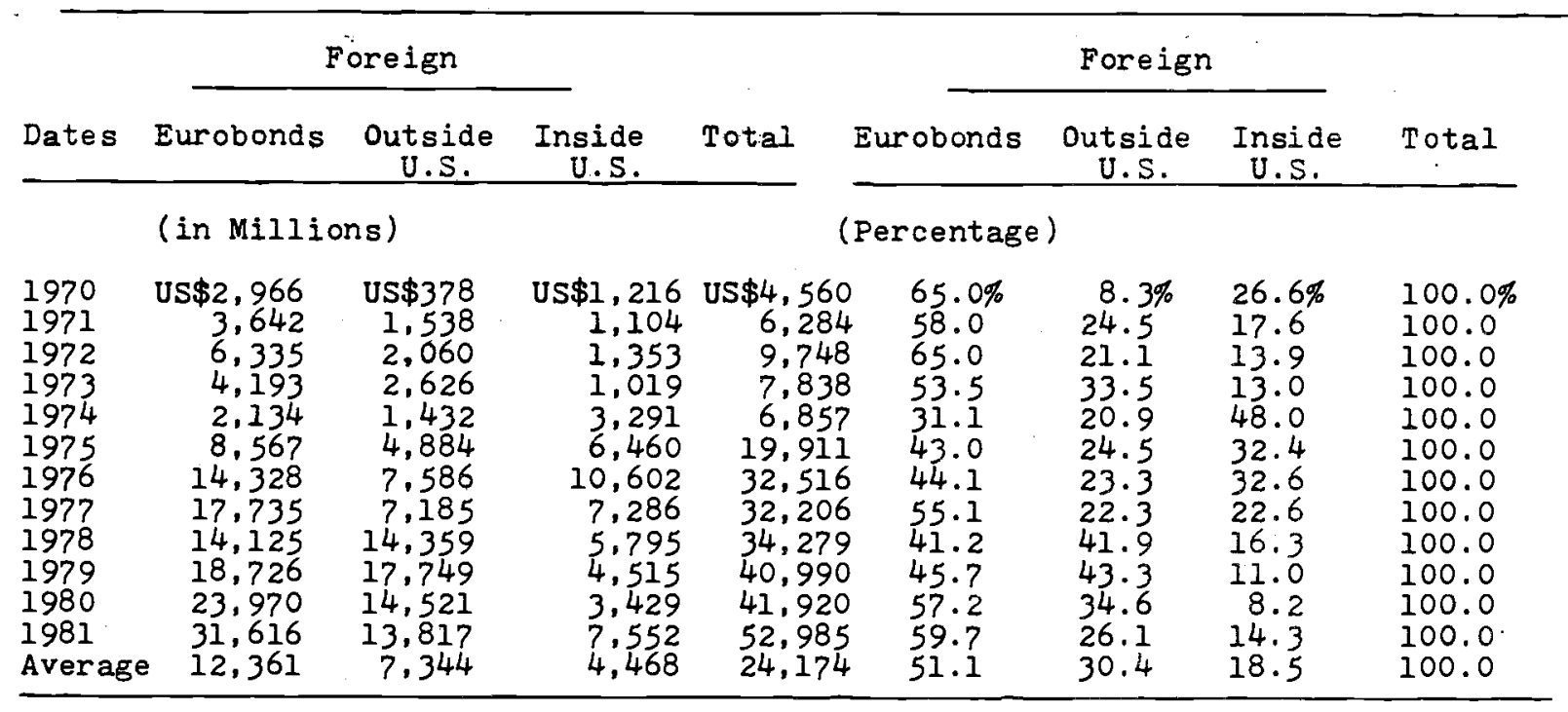

Source: Morgan Guaranty Trust Company, World Financial Markets, various issues 
We wish to focus our attention next on differences in regulatory treatment and issuing costs, factors that ought to influence the propensity of borrowers and lenders to converge on a particular market. We have been careful not to suggest that the Euro-bond market operates in a climate free from all regulation. While there is no official regulation of the Euro-bond market per se, every Euro-bond issue "must conform with the laws and regulations of the country in which it is offered for sale". ${ }^{12}$ However, this does not mean meeting local requirements for public offerings. For example, Euro-bonds may be offered for sale initially in the United States if they are registered with the SEC under the 1933 Act. Most Euro-bonds are not registered under the 1933 Act, but they can still be sold in the United States after distribution abroad has been completed, and they have been seasoned in the secondary market for 90 days. ${ }^{13}$ In practice, many foreign countries apply less restrictive regulations than exist in the United States, or apply fewer restrictions on Euro-bonds than on domestic bonds. In all cases, the method of offering Euro-bonds allows them not to be classified as "public offerings", and they are, therefore, not national securities subject to regulation. 14

Since Euro-bonds are issued under minimal formal regulatory control, the issuer avoids the kind of detailed and standardized disclosure requirements that are part of U.S. bond issues. Document preparation can be costly for U.S. issurers in the domestic capital market, but it may be prohibitive for non-U.S. firms in cases where accounting statements are not in accordance with American principles or where there is great reluctance to release certain 
$-12-$

Table 2 - COMPARATIVE CHARACTERISTICS OF BOND ISSUES

IN INTERNATIONAL BOND MARKGTS

Domestic Bonds

(U.S. Market)

1. Regulatory bodies

2. Disclosure requirements

3. Issuing costs

4. Rating required

5. Iisting

6. Queuing

7. Currency of denomination

8. Speed

9. Borrower/Issuer incentives

10. Lender/Investor incentives.
Securities and Exchange Commission

More detailed

-higher initial expense

-higher ongoing expense

- may be onerous to non-

U.S. firms.

$$
0.75-1.0 \%
$$

Yes

Iisting separate

No formal queue

U.S. does not restrict use of $\$$.

Relatively slow

- Rule 415 may speed up process.

Iarger market, greater depth Disclosure may be costly to foreigners

Greater depth and liquidity.

More standardized information disclosed.
Foreign Bonds Euro-bond Market (non-U.S. Market)

\begin{tabular}{|l|l}
$\begin{array}{l}\text { Official agency } \\
\text { approval } \\
\text { Variable }\end{array}$ & $\begin{array}{l}\text { Minimum regulatory } \\
\text { control } \\
\text { Determined by } \\
\text { markets practice }\end{array}$ \\
Variable to 4.0\% & $2.0-2.5 \%$ \\
Usually not & No \\
Listing usual & Listing usual \\
Usually queue & No queue \\
Many foreign & No restrictions on
\end{tabular}

countries (Germany, U.S., and

Switzerland) Canadian \$.

restrict use, part

of queuing.

Variable Usually fast

- "Bought deal"

Local visibility Lower annual interest piversification expense.

of sources

Speed of placement to capture advantageous windows.

Cannot sell issue in U.S. until 90 day seasoning.

furrency diver- furrency gains. sification gain Bearer bonds.

No withholding tax on interest.

Source: Adapted from Van Agtmael (1983), p. 5 . 
types of information to the public. Euro-bonds are very often exchange-listed(in Luxembourg, London or Singapore), and therefore, disclosure requirements must conform to exchange practices in those financial centers. Exchange listing is mainly a cosmetic device to increase the marketability of bonds among institutions and is not a necessary feature of Juro-bonds. In practice, very few secondary market transactions take place on the exchanges. 15 Regulation, therefore, is largely absent.

Unlike bond issues in the United States, the timing of domestic and foreign issues abroad is generally controlled by the local regulatory body. ${ }^{16}$ Queuing of new issues is an important tool of macroeconomic policy outside the United States. In this manner, governments seek to avoid "congestion" in the capital market, achieve interest rate targets, allocate places in the queue according to national economic or sectional priorities, and allow the government a clear run at local capital markets.

Although it is claimed that queuing regulations do not operate in the Euro-bond market, in fact this is only true in the U.S. and Canadian dollar segments of the market. 17 In other markets, notably Germany, Switzerland, and Belgium, the authorities do in fact regulate the issuance of Euro-bonds denominated in domestic currency. Again, these rules reflect the operation of macroeconomic policy within a small, open economy in which policymakers attempt to manage their exchange rate as well as interest rates. For domestic authorities, control over the volume of offshore issues denominated in domestic currency is important for achieving exchange rate and interest rate targets. Presumably, authorities could prohibit domestic sales 
of any unauthorized issue, which would effectively kill the market for it. Only the United States and Canada do not place restrictions on the use of their currencies for Euro-bonds. Mendelsohn (1980 p. 139) argues, therefore, that only the U.S. and Canadian dollar segments of the market are "true" Euro-bonds reflecting pure market forces.

Because of these regulatory differences, a Eurodollar bond issue can usually be organized and placed more quickly than a comparable U.S. domestic market issue. SEC Rule 415, permitting shelf registration, has reduced the time necessary to launch a U.S. domestic issue, but the advantage still resides with the Euro-bond market, especially in the case of a "bought deal". 19 speed allows the issuer the benefit of seizing favorable "windows" when interest rates are viewed as being unusually low.

Gross spreads in Euro-bond issues appear to be relatively high when compared to the U.S. domestic market, but moderate to low in comparison with other European markets (See Table 6, below). It is generally agreed that the selling concession built into Euro-bonds is relatively high, and that this plays an important role in primary market pricing--as we shall discuss in sections III and IV. Offsetting the high spreads, annual interest expense is generally lower in the Euro-bond market than in domestic markets. The average size of this interest differential is difficult to measure but, in May 1982, the yield advantage of the Euro-bond market to U.S. borrowers was roughly 75 basis points for a five-year issue.' Investors have been willing to pay a higher price for Euro-bonds than, for example, comparable domestic bonds of the same U.S. firm because Euro-bonds are generally issued in bearer form, and there are no taxes wihheld on interest payments. Recent U.S. legislation has removed the $30 \%$ withholding tax on new issues of government and corporate bonds 
sold to foreigners. This new development, plus the the possibility that U.S. Treasury securities may once again be issued in bearer form, may pose a considerable challenge to the Euro-bond market. However, historically, the actual cost of funds has been lower in either the Euro-bond market or domestic capital markets depending on prevailing conditions.

The overall growth in yearly Euro-bond issues is pointed out in Table 1. It is important to highlight other key dimensions of the market. Table 3 shows the breakdown of Euro-bond issuers. Almost half of all issues were by governments, state enterprises or international organizations. U.S. companies were responsible for $13.5 \%$ of all issues. The distribution of Euro-bond issues by currency of denomination is reported in Table 4. Overall, the Eurodollar segment accounts for two-thirds of the market, but there is considerable variation from year to year. In 1978, when the dollar was declining sharply on foreign exchange markets, the Eurodollar segment was $51.6 \%$ of the market. In 1981, with foreign exchange conditions reversed, the Eurodollar share reached $85 \%$. The average size for new Eurodollar issues exceeds $\$ 70$ million, slightly larger than for non-dollar denominated issues. Secondary market trading in Euro-bonds has grown simultaneously with new issue volume, as illustrated in Table 5. The average maturities for new Euro-bond issues is plotted in Figure 1. The general trend for maturities is clearly downward reflecting the increase in risks associated with interest rate and exchange rate volatility. 
Table 3 EUROBOND ISSUES, 1972-1981

\begin{tabular}{lrc}
\hline & Value (in millions) & Percentage \\
\hline U.S. companies & US\$19,088 & 13.5 \\
Non-U.S. companies & 52,855 & 37.3 \\
State enterprises & 35,777 & 25.2 \\
Governments & 20,743 & 14.6 \\
International organizations & 13,266 & 9.4 \\
\hline
\end{tabular}

Source: Morgan Guaranty Trust Company, World Financial Markets, various issues. 


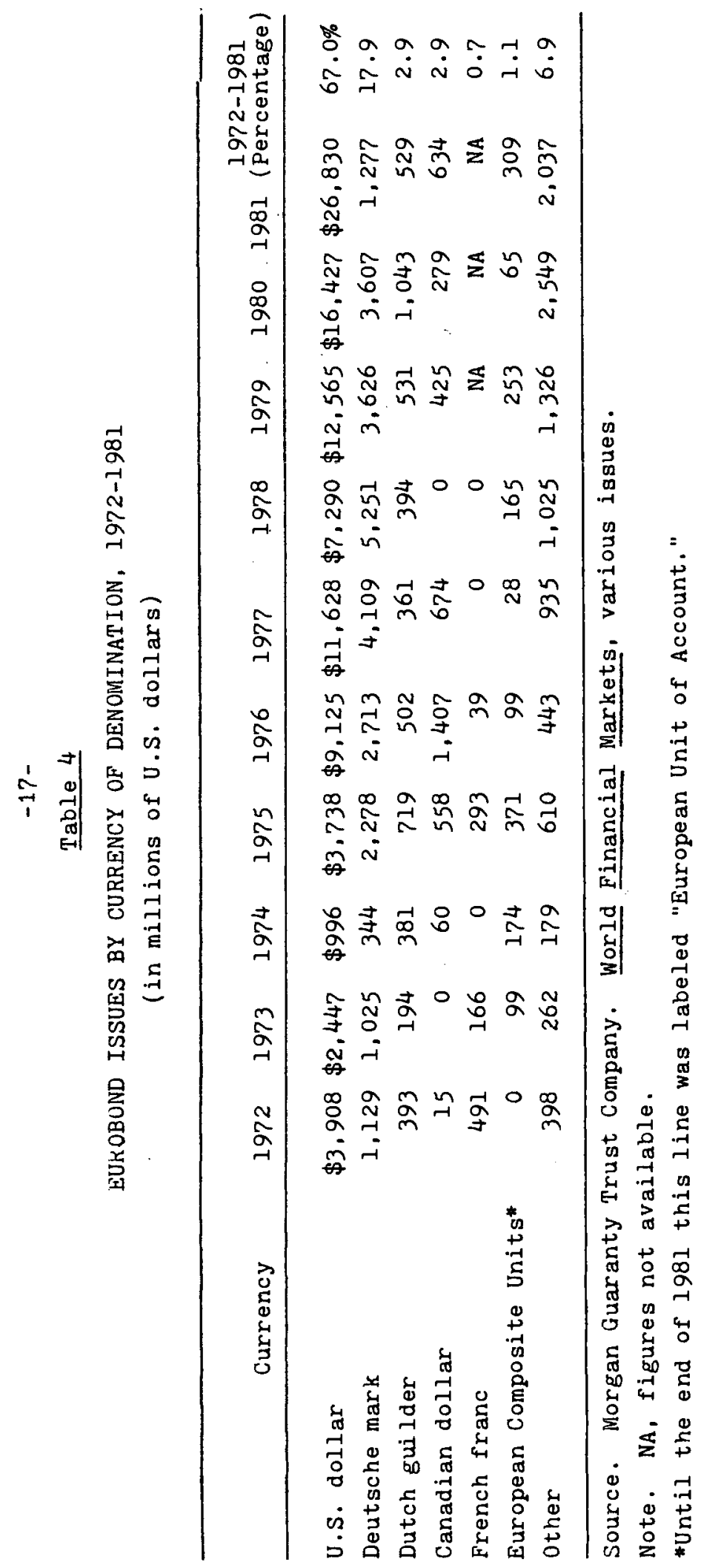


Table 5

SECONDARY NIARKET TURNOVER:

TRADING VOLUME, 1972-1982

(里bilion equivalent)

\section{Euroclear $\quad \underline{\text { Cedel }} \quad \underline{\text { Total }}$}

$\begin{array}{rrrr}1972 & 11.0 & 6.0 & 17.0 \\ 1973 & 11.1 & 10.2 & 21.3 \\ 1974 & 8.2 & 8.1 & 16.3 \\ 1975 & 14.3 & 14.2 & 28.5 \\ 1976 & 37.0 & 29.7 & 66.7 \\ 1977 & 65.2 & 38.6 & 103.8 \\ 1978 & 77.1 & 39.7 & 116.8 \\ 1979 & 102.8 & 54.7 & 157.5 \\ 1980 & 160.5 & 80.3 & 240.8 \\ 1981 & 242.0 & 155.0 & 397.0 \\ 1982 & 510.0 & 332.0 & 842.0\end{array}$

Sources: Years 1972-1980 are from Fisher (1980, p. 177). Years 1981-1982 are from Koenig (1983).

Note: Total excludes the majority of Deutsche mark denominated bonds which are handled through the German Kassenvereine system. 
GROWTH IN EUROBOND ISSUE SIZE, 1963-80 (average issue amount $\$$ million equivalent

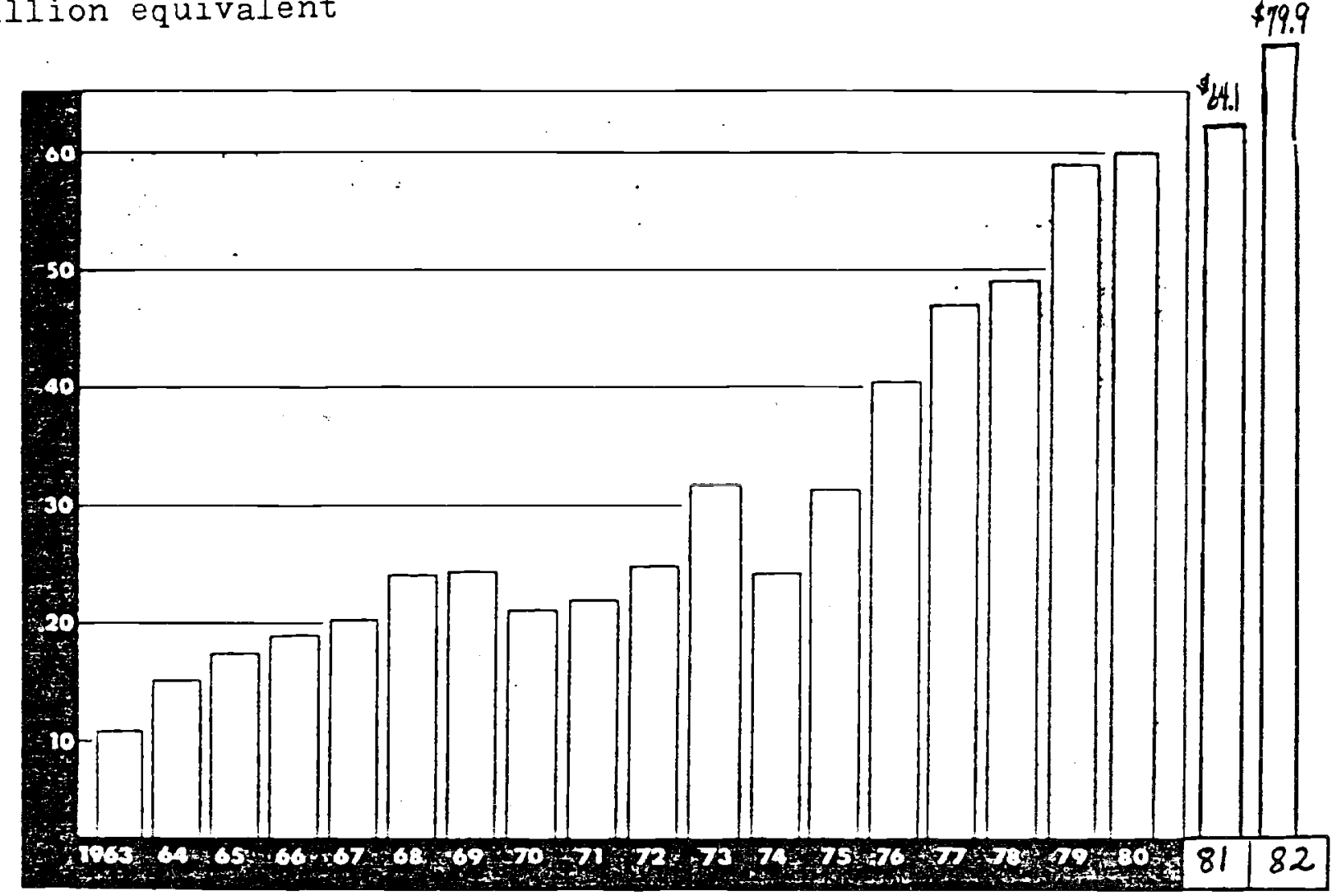

GROWTH OF EURODOLLAR BOND ISSUE SIZE, 1963-80 (average issue amount \$ million)

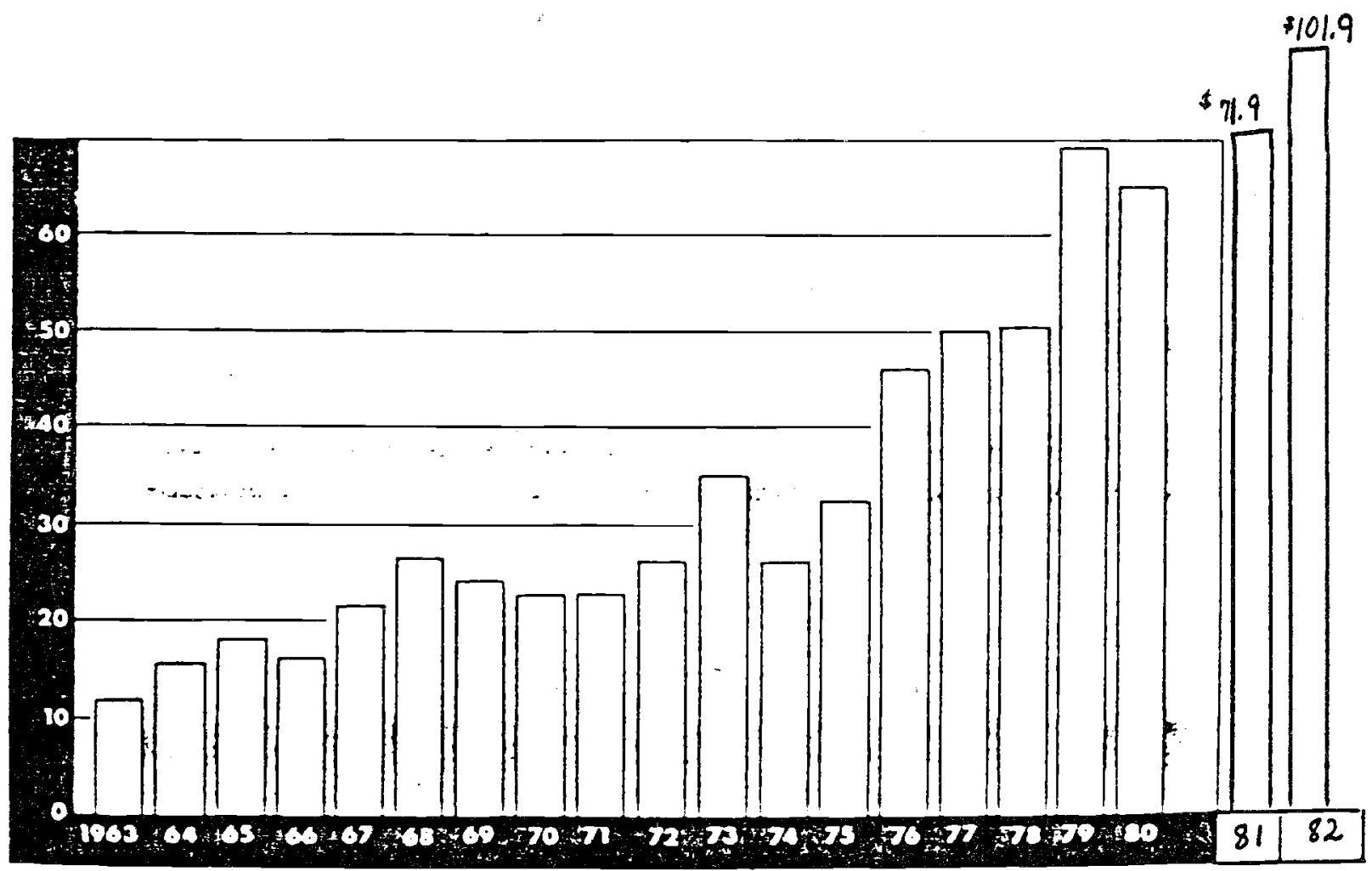


III. Appraising the Performance of the Euro-bond Market

In this section we offer an anlysis of the performance of the Euro-bond market as an institution. We begin by describing the initial conditions when the first Euro-bond issues were launched. A discussion of strategic steps taken by Euro-bond underwriters in order to develop the market follows, and we then assess the competitive conditions that have resulted in Euro-bond underwriting.

\section{Economic Policies and Euromarkets in 1963}

As noted earlier, the first Euro-bond issue occurred in 1957. Over $\$ 500$ million was raised through 22 Euro-bond issues over the period 1957-1962.

Around this time, the Eurocurrency market -- the offshore market for short-term loans and deposits -- was taking shape. Given the large share of international transactions denominated in dollars, it was reasonable to predict that non-Americans would soon demand longer-term offshore assets denominated in dollars, as well as Eurocurrency deposits. While natural forces were in place, the development of the Euro-bond market was enhanced by the enactment of the Interest Equalization Tax in the United States on July 18, 1963.23 The IET was proposed as a temporary measure to reduce U.S. capital outflows and take pressure off the U.S. balance of payments deficit. The IET operated like an excise tax on American purchases of new or outstanding foreign stocks and bonds. To no one's surprise, the IET effectively closed the Yankee bond market; to the surprise of some, the foreign borrowers simply migrated offshore to London and Luxembourg. ${ }^{24} \mathrm{~A}$ second major stimulus to the development of the Euro-bond market was the imposition of the Office of Foreign Direct Investment (OFDI) 
controls on U.S. multinationals financing of their overseas ventures. The controls began in February 1965 on a voluntary basis and were made mandatory in January 1968 to reduce U.S. capital outflows and improve the balance of payments. By 1968, the OFDI controls effectively forced U.S. multinationals offshore to meet their financing needs for foreign projects.

Both the IET and OFDI controls were extended several times until January 1974 when both were scrapped. In 1974, with both foreign borrowers and U.S. muItinationals free to use U.S. capital markets, the volume of Euro-bond issues fell to $\$ 2.1$ billion, its low for the decade. However, volume has been rising sharply and more or less steadily ever since.

The Euro-bond market has survived and prospered because it satisfies economic demands that are not fulfilled by other markets. Earlier, it was suggested that some demand for Euro-bonds is natural since many non-Americans desire to issue or hold dollardenominated securities. Demand was increased further because securities sold by U.S. companies domestically are generally in registered form, and until July 1984, the United States applied a 30\% withholding tax on interest payments to foreigners. One could also argue that for some groups of borrowers (e.g., large, well known firms) and investors (e.g., large, well informed), domestic security market regulations represent a disincentive that can be reduced with little risk by taking transactions offshore. 25

Fisher (1981, p. 19) notes with appropriate irony that the U.S. IET controls, "intentionally prejudicial" to non-American borrowers, ultimately led to the "largest international capital market the world has known". The 1963-74 period of relative protection was essential for 
Euro-market participants to develop professional relationships among themselves, client relationships with issuers, as well as the issuing techniques appropriate to the new market. 26 However, it would be a mistake to assume that the Euro-bond market developed in a risk-free environment. As in any securities market, interest-rate and credit uncertainties led to investment and underwriting risks. In addition, the unit of account for most Euro-bonds was foreign to most investors, and so underwriters faced the risk that demand for bonds would shift because of unexpected exchange rate movements. As we have seen (Table 4) investors were more willing to accumulate an issue if the unit of account was expected to appreciate. Existing Euro-bond underwriters always faced the risk that the IET would be scrapped, and in 1974 , when the IET was finally eliminated and OFDI controls were phasedout, Euro-bond market volume collapsed to one-third the level of 1972 (Table 1). Finally, as there were no regulatory barriers to entry, existing underwriters have faced the risk of entry by new competitors. And as we have seen, this competition may also come from the U.S. domestic market now that withholding taxes on interest payments to foreigners have been abolished. 


\section{Strategies of euro-bond Underwriters}

To operate in this new market, Euro-bond underwriters developed a variety of strategies and techniques to expand the market while controlling risks. The standard syndicate structure in the Euro-bond market is described by the three-tier framework illustrated in Figure 2. Members of the underwriting syndicate agree to buy the issue from the issurer. In the U.S. domestic market, all underwriters are signatories to the underwriting agreement, and, therefore, have a "direct (several) obligation to the issuer."27 In the Euro-bond market, "underwriters" (as the term appears in Figure 2) bear no obligation to the issuer. ${ }^{28}$ There is also a selling group with no underwriting responsibility. Once an allocation of securities is made, all parties are free to sell the issue as they see fit. 29 The lead management group attempts to instil discipline through economic incentives and disincentives, such 
Figure 2

THREE-TIER FRANEWORK FOR EUROBOND SYNDICATION

Tier no. 2

(1)

Fiscal agent or trustee and principal paying agent

(2)

Issuer

-

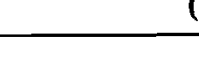

$\longrightarrow$
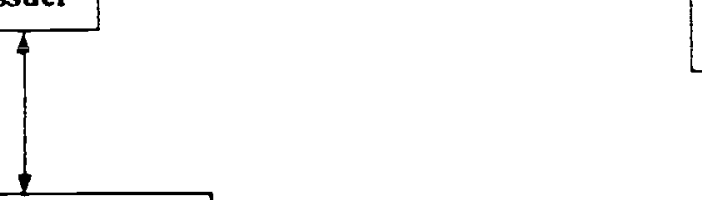

(6)

Tier no. 1

$$
\text { Management group }
$$

(3)

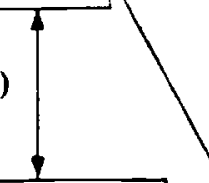

\section{Underwriters}

(4)

(6)

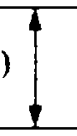

nvestors

Tier no. 3

Selling group

(5)

Source: Fisher (1981), p.75. 
as refusing to invite a seller into future syndicates. Large syndicates are used in efforts to maximize market demand and insure a successful issue. In the late 1970's, underwriting groups became as large as 175 firms, with an additional 150 members in the selling group. 30 Naturally in groups this large, some members would not be able to place their full allocation, resulting in price-stabilization and discipline problems for the lead managers. Because Euro-bonds are chiefly in bearer form, members of the selling group could unload unwanted bonds in a discreet way with little probability of being traced. 31

The grey market or pre-market involves a set of activities that formalize trading in Euro-bonds prior to the official offering date. Professional dealers display their transaction prices over the Reuters Monitor and a market price is established. 32 Other sources publish grey market prices more widely. 33 The grey market reduces risks for members of the selling group by allowing them to participate in an organized market if conditions (demand for bonds, interest rate or exchange rate developments, etc.) do not evolve as expected. The grey market also alleviates risks for lead managers because it provides additional information on the market's response to the issue (i.e., the extent of dumping) and whether the terms of the issue ought to be altered. The grey market can, in addition, provide information on the extent of "overpricing" to investors who pay full price on the day of issue. This concern arises because, as we noted in Section II, there is reason to believe that spreads (in particular the selling concession) are relatively high on the Euro-bond market. A large selling concession may have been appropriate in terms of sales to individuals or as a sweetener to attract sellers in a newly 
developing market. But large institutional buyers in the Euro-bond market have had the power to force distributing groups to share all or part of the selling concession. 34 The market can thus exhibit a two-tier pricing system on any given issue. 35

Nanagers and underwriters in the Euro-bond market have adopted a number of straightforward procedures to increase the demand for bonds and to be compensated for additional risks. The Euro-bond market began as a market for high-quality borrowers, and themarket continues to be dominated by recognized names. Higher quality compensates for limited information disclosure. 36 Most Euro-bonds are listed on stock-exchanges, primarily as a marketing device to make the securities eligible for some institutional portfolios and promote investor confidence. Both Moody's and Standard \& Poor provide Euro-bond ratings services. Spreads increase with the maturity of Euro-bonds (see Table 6) to compensate for the greater risks involved. 37 We have also observed the average maturity of Euro-bonds has declined (see Figure 3) as interest-rate risk has increased.

Euro-bond underwriters have invented or adapted other innovative syndication approaches and issuing techniques. Prior to 1979 , the standard Euro-bond invitation telex included the expected coupon rate based on current market conditions. In contrast, U.S. domestic issues were priced on a yield basis after intensive discussions between the lead manager and other syndicate members. Consequently, a U.S. syndicate could better fix a yield consistent with secondary market conditions and investor demand. Coupon, issue price and total commissions were set after the selling period without being indicated in the invitation telex. The Euro-bond market adapted this U.S. market practice, known as yield pricing, enabling the lead manager to work with a smaller syndicate, improve pricing control, better estimate demand and reduce the need for discipline. 
The bought deal or pre-underwritten issue was introduced in early 1979. The underwriter telexes that funds are available on specific terms for a short period. If the deal is accepted and successful, the issue should close quickly, the lead manager alone placing most or all of the issue. Under volatile market conditions, the speed of a bought deal is valuable to issuers, but the manager is exposed to greater underwriting risks. 39

other examples of issuing techniques are the auction issue, conversion issue, multiple-tranche issue, deferred purchase issue, convertible issue, issues indexed to commodities or currencies, and issues with warrants attached. ${ }^{40}$ To some extent, these techniques may be viewed as fads or sweeteners to address uncertainties that momentarily concern the market. However, some issuing innovations, like floating rate notes, have captured substantial market shares and seem to be a permanent and growing feature of the market. ${ }^{41}$ Finally, we should mention the role of Euro-clear and cedel, the two computerized depositary, clearing and information networks for the Euro-bond market. Both systems were founded by private parties--Euro-clear in 1968 by Morgan Guaranty Trust Company and Cedel in 1971 by a group of shareholder institutions. In 1972, Morgan Guaranty sold of $97 \%$ of its interest in Euro-clear to a group of 120 user shareholders, ${ }^{42}$ but continues to manage the system. In 1980, a bridge linking the two systems came into operation. 43 
$-27-$

(a) EUROBOND MATURITIES: YEARLY WEIGHTED AVERAGE, 1963-80

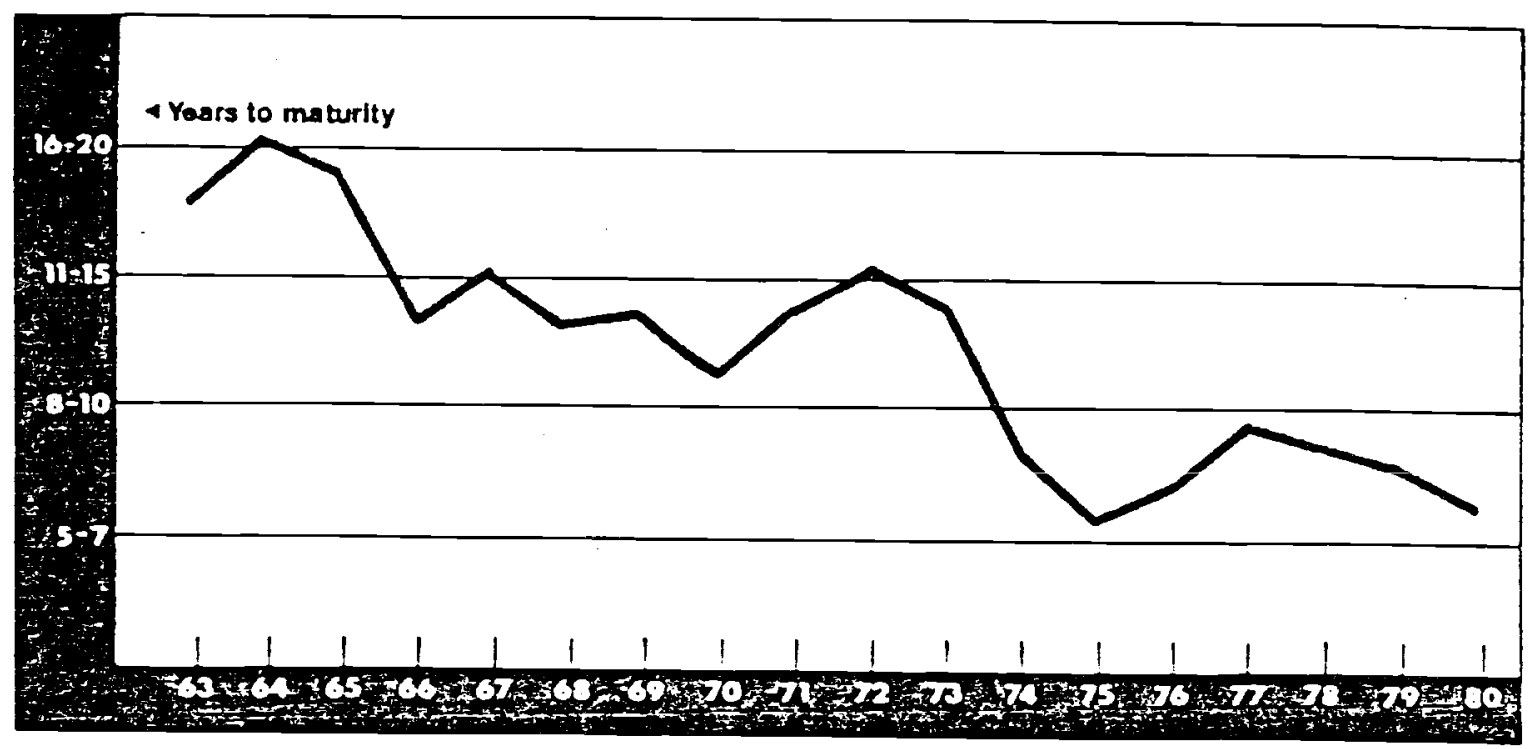

Source. Inter-bond Services Lid.

(b) AVERAGE EURO-DOLLAR BOND NATURITIES, 1963-80\%

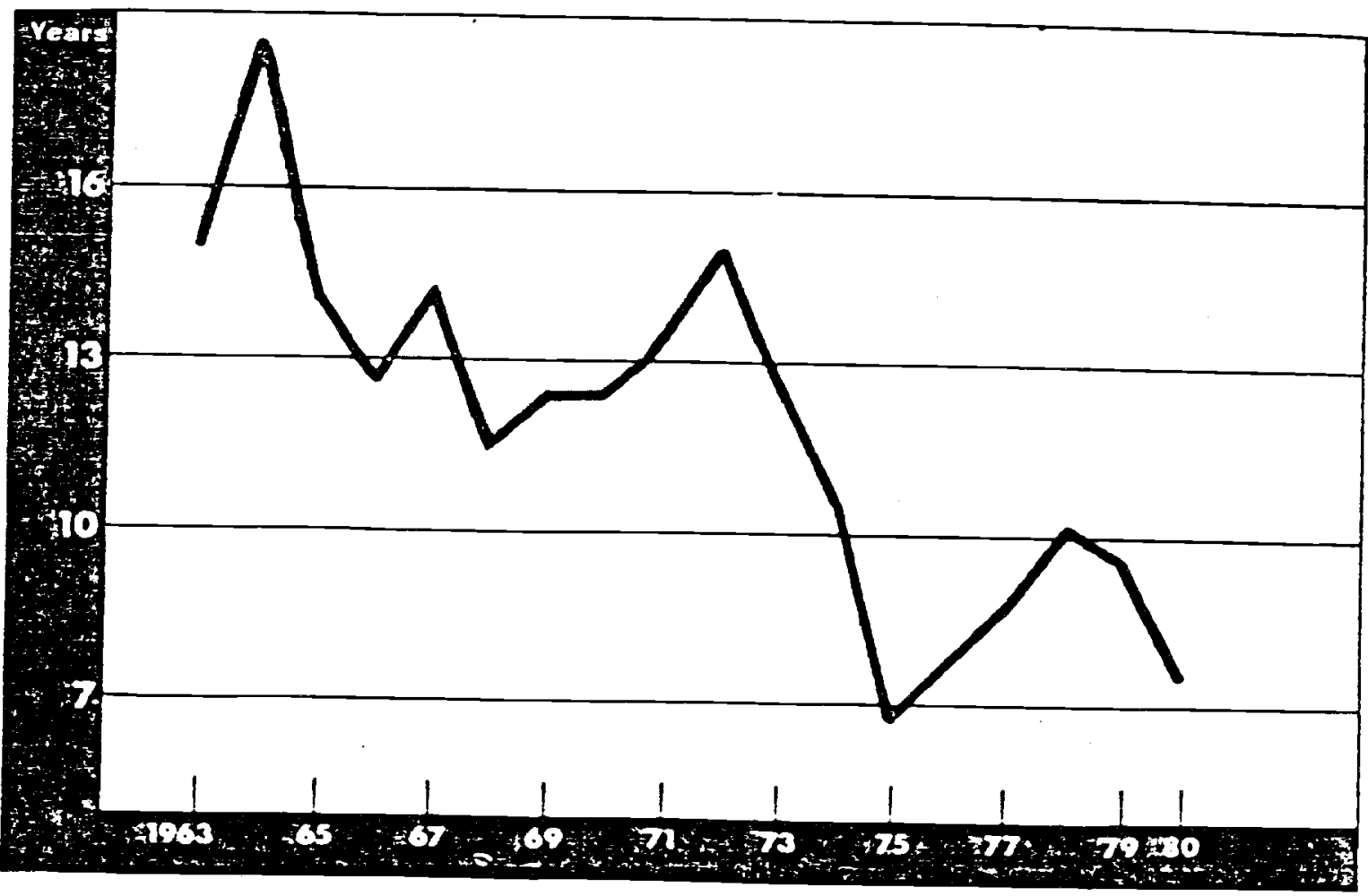

- Excluding convertible bonds.

Source. Inter-bond Series Lid. 
Fisher (1981, p. 182) argues that competition has forced the two systems to become increasingly similar, but Euro-clear maintains a two-thirds market share (see Table 5). Both systems, in conjunction with the Reuters Monitor, have improved the technological efficiency of trading in the Euro-bond market and promoted new-issue volume.

\section{Assessing Competitive Conditions in the Euro-bond Market}

In an important sense, a free market that grows from non-existence to $\$ 50$ billion annual new issues in twenty years is a success, by definition. Clearly, the Euro-bond market brings together a large number of willing borrowers and lenders with substantial benefits to both groups. Beyond gains to the direct participants, the market fills a gap in international capital markets, speeding the traditional recycling of funds in the 1970s and allowing time for adjustment between deficit and surplus economies. 44 our objective now is to characterize the orderliness $\quad \therefore$ of that free-market setting.

First, in the entire history of the Euromarkets, no bank has failed solely or even mainly because of Euromarket lending. 45 The worst shock to hit the market was the failure in June 1974 of Bankhaus Herstatt, a relatively small German institution. The collapse of Herstatt was the result of imprudent foreign exchange activities. In terms of bond defaults, Nendelsohn (1980, p. 50) reports that in the period 1963-1977, \$72 billion was raised through 2700 Eurobond issues. Losses to investors were $0.24 \%$ ( $\$ 170 \mathrm{million}$ ) because of default by 10 small U.S. companies. 46

The composition of leading Euro-bond issuers has changed considerably during the history of the market. The top 20 underwriting 
Table 6 -Comparative Gross Spreads in International Bond Markets

$\begin{array}{ccc}\text { Underwriting } & \text { Management } & \text { Selling } \\ \text { Total Commission } & \text { fee } & \text { Concession }\end{array}$

U.S. domestic market

$\begin{array}{llccc}\text { - estimate 1 (a) } & 0.875-1.0 \% & 0.175 & 0.200 & 0.500 \\ \text { - estimate 2(b) } & 0.75-1.0 & \text { NA } & \text { NA } & \text { NA } \\ \text { - estimate 3 (c) } & 0.60-1.5 & \text { NA } & \text { NA } & \text { NA }\end{array}$

Inited Kingdom (d)

$2.5 \%$

NA

NA

NA

- domestic bond market

jermany

(e)

- Stocks

$$
4.0 \%
$$

NA

NA

NA

- Bonds Public

Industrial

$1.625-2.0$

$0.375-0.5$

2.5

1.00

$0-0.25$

0.25

$1.75-2.0$

$0.50-0.75$

0.25

1.12

-1.25
1.25
1.00

France

(f)

- Bonds

First catezory

Second category

$1.75 \%$

3.00

0.50

0.75

0.10

0.25

1.15

2.00

Switzerland

(g)

- Eonds

Government

Foreign

$1.50 \%$

3.00

NA

NA

NA

NA
NA

NA

Eurobond market $(h)$

Under 5 years

5-8 years

more than 8 years
$2.00 \%$

2.25

2.50
0.375

0.375

0.500
0.375

0.375

0.500
1.25

1.25

1.50

INotes: a) Miendelsohn (1980, p. 183) and Niendelsohn (1983, p. 18)

b) Van Agtmael (1983, p. 5)

c) Fisher (1981, p. 81)

d) Maycock (1983, p. 5)

e) Dufey and Krishnan (1983, p. 22)

f) Aftalion and Bompaire (1983, p. 7)

g) Corti (1983, p. 40 and p. 45)

h) livendelsohn (1980, p. 184) 
Table 7 - Top 20 Underwriting Firms in The

Eurobond Market as of 1982 and Their Panks in Earlier Years.

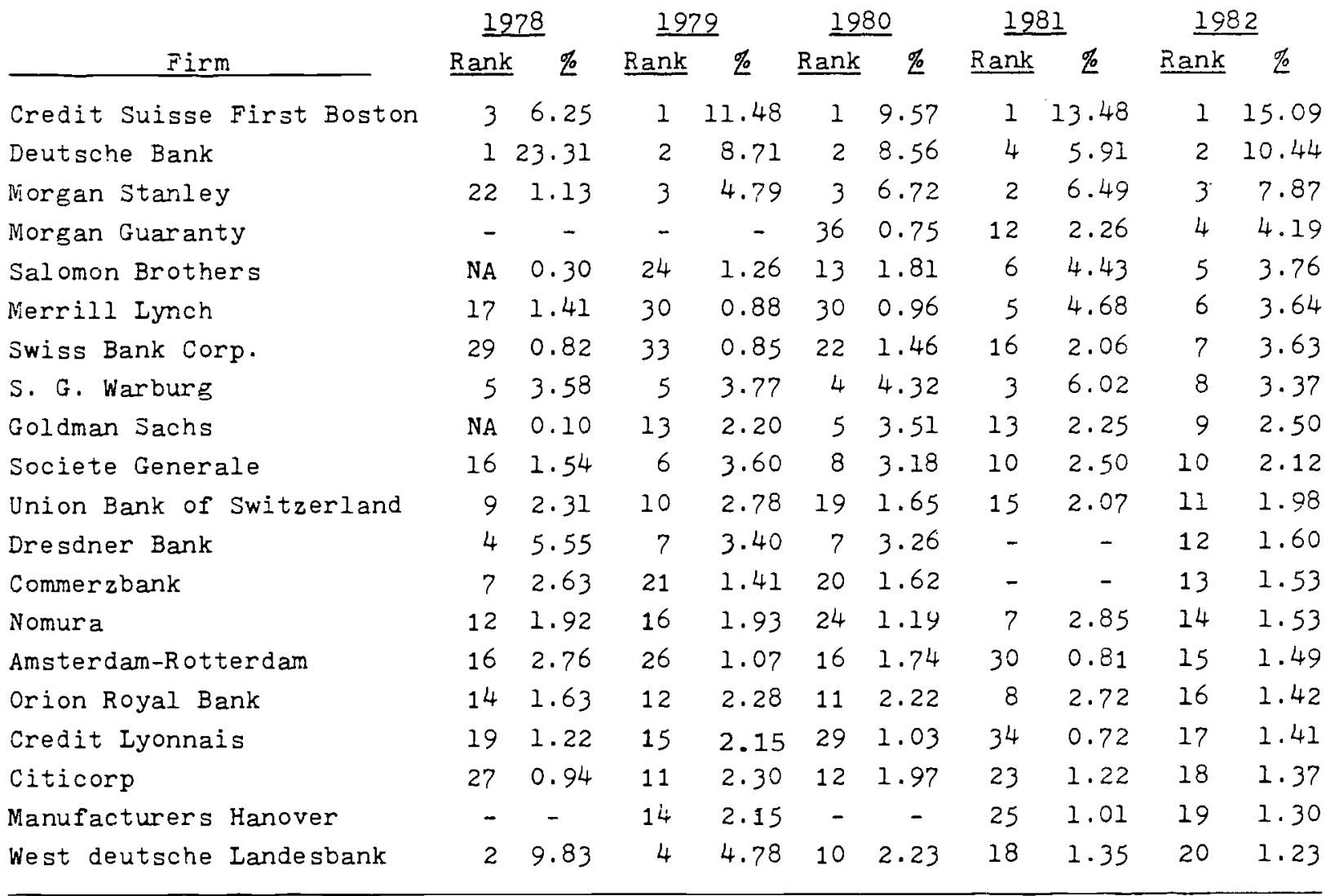

Note: Euro-bonds include Floating Rate Notes and bond issues in all currencies. Percentages are calculated by allocating the full amount of the issue to sole lead managers and equal amounts to joint lead managers.

Source: Prepared by $\mathrm{Cl}$ ifford Austin Billinghurst for Morgan Guaranty Ltd., London. 
firms as of 1982 and their rankings since 1978 are given in Table 7 . Among the top 10 firms in 1982, we find five American firms. Of the top 10 firms in 1978, only three(Credit Suisse First Boston, Deutsche Bank, and Warburg) remained in the top-10 of 1982. Part of the shuffling of ranks is the result of exogenous events--DM weakness on the foreign exchange market prompted the German authorities to be cautious about allowing new Dim issues (almost always led by German banks), continued dollar strength has increased demand for Eurodollar bonds (often managed by U.S. houses) and U.S. borrowers have returned in large numbers to the market (generally choosing U.S. underwriters ). In 1978 the situation was reversed, and German and Swiss banks dominated the list with only two U.S. houses in the top 20. Fiendelsohn (1980, p. 194) notes that, going back 10 years further, U.S. houses again dominated the list as American companies, driven away by OFDI requirements were heavy borrowers. Only in the 1970 s did "placing power" assume importance and cause the Swiss, German, and other European banks to enter into the top ranks of underwriters.

Concentration ratios for Euro-bond underwriters are reported in Table 8. Percentage shares are calculated by awarding full credit to a sole lead manager and equal proportional credit to joint lead managers. The data suggest a slight decline in concentration among the top 10 houses, but this may reflect the decline in the role of the DIf after 1978. Comparable ratios for U.S. investment banking are shown in Table 9, which gives full credit to the firm that runs the books. The market share of the largest firm is approximately the same in both the U.S. and Euro-bond markets. However, 


\begin{tabular}{|l|l|l|l|l|l|}
\hline Top 1 & 1978 & 1979 & $\underline{1980}$ & $\underline{1981}$ & $\underline{1982}$ \\
Top 4 & $23 \%$ & $11 \%$ & $10 \%$ & $13 \%$ & $15 \%$ \\
Top 5 & 45 & 30 & 29 & 32 & 38 \\
Top 8 & 59 & 34 & 33 & 37 & 41 \\
Top 10 & 61 & 44 & 43 & 47 & 52 \\
Top 15 & 70 & 60 & 57 & 52 & 57 \\
Top 25 & 32 & 76 & 72 & 76 & 77 \\
\hline
\end{tabular}

Source: Prepared by Clifford Austin Billinghurst for Morgan Guaranty Ltd., London.

Note: Eurobonds include Floating kate Notes and bond issues in all currencies. Percentages are calculated by allocating the full amount of the issue to sole lead managers and equal amounts to joint lead mangers. 
Table 9

U. S. Concentration Ratios in the

Underwriting business 1975-1983*

\begin{tabular}{|l|l|l|l|l|l|l|l|l|l|}
\hline & & 1975 & 1976 & 1977 & 1978 & $\frac{1979}{1980}$ & 1981 & 1982 \\
Top 1 & $21 \%$ & $23 \%$ & $24 \%$ & $23 \%$ & $18 \%$ & $13 \%$ & $18 \%$ & $18 \%$ \\
Top 4 & 55 & 59 & 57 & 57 & 55 & 50 & 56 & 60 \\
Top 5 & 63 & 66 & 64 & 64 & 63 & 59 & 64 & 69 \\
Top 8 & 79 & 79 & 78 & 80 & 79 & 79 & 78 & 83 \\
Top 10 & 87 & 85 & 83 & 86 & 85 & 84 & 84 & 88 \\
Top 15 & 97 & 92 & 93 & 94 & 94 & 93 & 92 & 95 \\
Top 25 & 100 & 97 & 99 & 98 & 98 & 98 & 97 & 99 \\
\hline
\end{tabular}

* Investment Deaiers Digest annual Directories of corporate finance for 1975 to 1982. Percentage of total dollar volume of underwritings using figures giving full credit to the manager handing the books.

Source: Morgan Guaranty Trust Company 
the concentration ratios for the largest 5 through 25 firms is considerably smaller in the Euro-bond market. The inference is that competitive forces are greater among Euro-bond underwriters.

Note that affiliates of U.S. commercial banks listed in Table? include Morgan Guaranty, Citicorp, and Nanufacturers Hanover.

In their study of U.S. investment banking, Hayes, Spence and Marks (1983, p. 55) argue that the stability of client relationships over time is a significant indicator of competition. Switching of relationships suggests the presence of competitive forces, while inertia in relationships may create a persistent state of market disequilibrium. The authors conclude that while relationships give the appearance of fluidity, the major apex firms have maintained a firm hold on the large and important clients in the U.S. domestic market. However, we may expect to observe some differences between "bought deals" and Regulation 415 issues, which appear to be making the U.S. market more competive.

Evidence from the Euromarket suggests a considerable degree of switching among management syndicates. Mendelsohn (1983, p.12) notes that while a few major firms may dominate the rankings, "one does not find the same group of managers united in an offering with monotonous regularity." An analys is by Euromoney of two top-ranking underwriters, Crédit Suisse and Deutsche Bank, drew similar conclusions."

Finally we compiled data on the number of lead managers used by issuers with three or more Eurodollar bond issues outstanding (see Table 10). For the sample of 107 issuers, $75 \%$ had used the services of two or more lead managers. For the entire group, the average 
Table 10 Number of Lead Managers for Agencies with Three or More Euro-dollar Bond Issues(a).

Number of Lead Nianagers

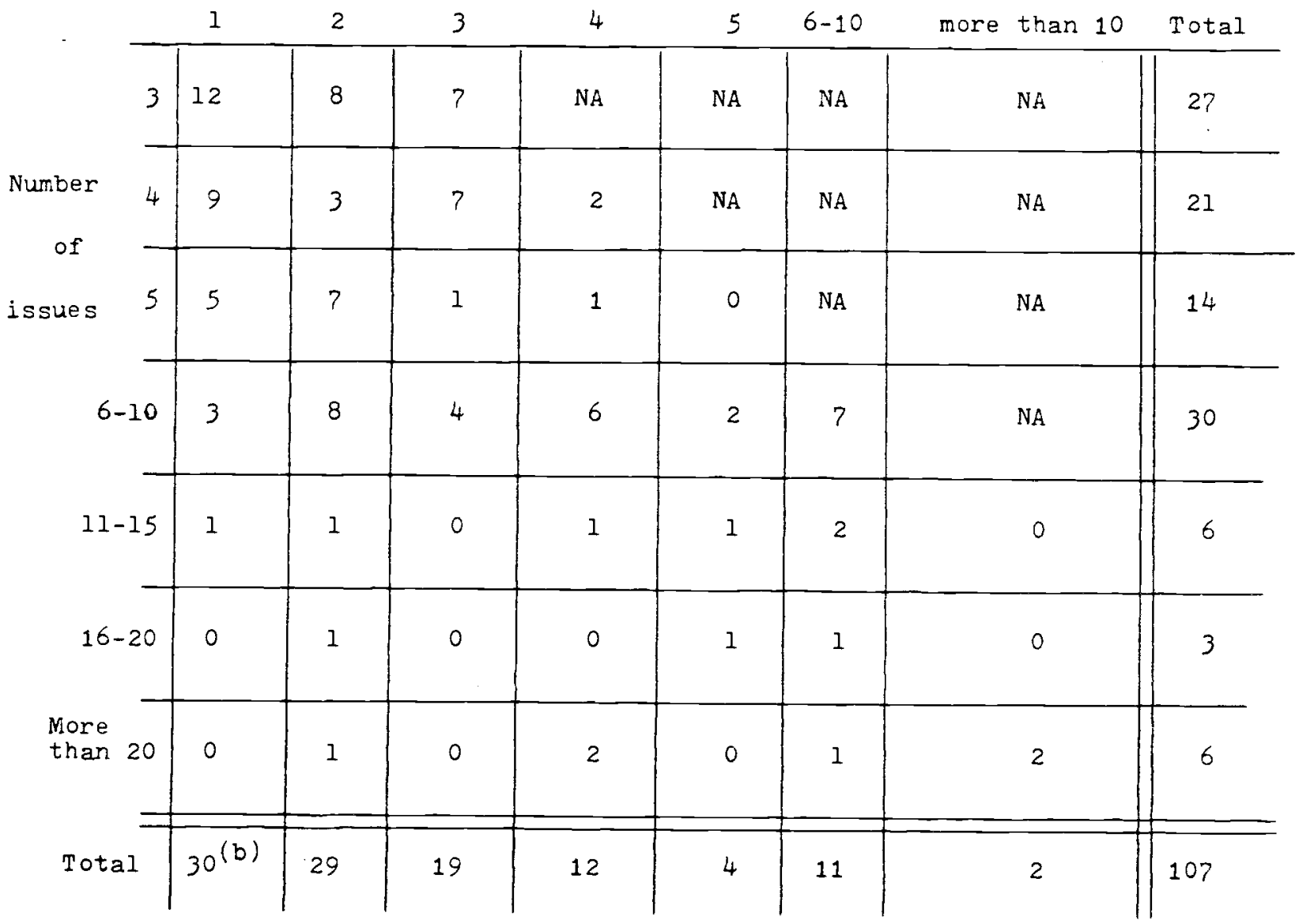

Source: Weekly Eurobond Guide, October 28, 1983

Notes: (a) Reflects issues outstanding on October 28, 1983. Agencies include corporations, governmental bodies, and supranational agencies. Bond issues include straight bonds, zero coupon bonds and floating rate notes.

(b) Includes 5 banks who lead managed all of their own issues.

For all companies with three or more issues, percentage with two or more managers is $77 / 107=75 \%$. 
number of issues is about six and the average number of managers nearly three. This reflects both aggressive bidding for new business by underwriters and the willingness of issuers to switch lead manager affiliations.

IV. Problems and Risks in the Euro-bond Narket

The evidence in Sections II and III portrays the Euro-bond market as a dynamic and highly competitive market. Our objective now is to describe some of the most serious criticisms that have been made concerning Euro-bond market operations. Since the

Euro-bond market operates subject to a minimum of regulations, it is reasonable to ask whether the U.S. domestic securities market might develop similar "problems" if barriers restricting competition in securities underwriting were removed. It is important to keep in mind that the Euromarket began de novo only about 20 years ago, making it essential to distinguish temporary from permanent problems. We shall also stress that what may be perceived as "problems" for individual firms--for example, being forced out of the market--may simply reflect the natural operation of competitive forces that are desirable from a broader perspective.

\section{Degree of Competition}

Problems of excessive competition in the Euro-bond market have been cited for the last ten years. The alleged problem manifests itself in two ways: (1) Too many houses competing for a position on tombstones; and (2) Mispricing caused by houses bidding too aggressively for new issues. Obviously, these are relative statements. 
Problem (1) implies that there may be too many houses competing relative to the number that would allow existing houses to make "fair" underwriting profits. The sense of (2) is that new issues, priced ex ante with incomplete information, may appear mispriced relative to the price necessary to clear the market ex post, after the actual market demand has been revealed.

Regarding the first point, Wiendelsohn (1980, p. 185) argues that "most banks are in the new issue market for prestige rather than money." With simple arithmetic, it is easily shown that underwriting returns are heavily skewed toward the managers, and the remainder of the selling group receives very little. 48 Gewirtz $\left(1983^{b}\right)$ maintains that rankings on the league table of active issuers may be important, but many houses see their presence in the Euro-bond market as defensive. A house that cannot service a borrower offshore may lose his business onshore as well. Many houses are still small but expect to grow, covering current underwriting losses with secondary market trading profits. 49

The first problem of many houses competing for business contributes to the second problem. If an oversupply of houses is vying for syndicate participations, lead managers will be encouraged to bid more aggressively for new issues. Gewirtz (1983b) concludes that "as long as underwriting syndicates are used to swallow mispriced deals, the problem will never go away". However, as long as competition does not destablize the system, it is really immaterial that some institutions lose money on some deals.

The excess competition problem is a serious one because it leads to other difficulties. Houses that accept allocations for 
prestige may have to dump their securities in the grey market. Houses without placing power may be easy targets for professional buyers seeking discounts. This leads to two-tier pricing and problems of syndicate discipline, although not necessarily problems from the point of view of institutional safety and soundness.

While shortages or surpluses sometimes arise in a particular market, when competition exists these conditions are both temporary and self-correcting. In 1977, Euromoney commented that while "Underwriters are given several opportunities to drop out of an issue... in the Euromarkets underwriters seldom drop out...not only because they would lose their underwriting fee, but they would lose face with the manager if they 50 did so." Less than four years later in an article focusing on the return of realistic pricing, Euromoney reported that as a consequence of past losses, "banks increased the number of underwritings they refused. The refusal rate, it is thought, was running at $30 \%$ at the end of last year. This has almost certainly increased to over 50\%."51 Continuing the trend, Engel (1983) notéd "sharply reduced willingness of banks to support mispriced issues." 52 He argued that the development of a highly liquid grey market has permitted managers to observe. prices first-hand. "The mechanism (of the grey market) is so effective and so anonymous that some lead managers have ended up buying virtually the whole of an issue whose price they chose to defend." 53

Thus, for the moment, the problem of excess competition appears to have eased. Syndicate members have some scope for refusing mispriced deals, and lead managers have increased incentives for accurate pricing. 
Secondary Wiarket Liquidity

Closely related to primary market problems is the efficiency of secondary market transactions. Mendelsohn (1980, p. 195) indicates that the secondary market for Euro-bonds used to be described "accurately, if unkindly, as consisting of a broker telephoning himself." This is still the case for some among the 3,600 Eurobond issues currently outstanding. 54 Liquidity was not an essential factor in the early days of the market, when bonds were held to maturity primarily by individual investors. Now that institutional buyers dominate the market, liquidity is an important factor. Engel (1983, p. 24) argues that it will cost borrowers more if the manager does not have a long-term commitment to the issue in the secondary market. Lead managers generally respond that their primary responsibility is to the issuers and not other professional market makers. They participate in market making, but capital ałlocated to this activity must be balanced against other considerations. 55 By some measures--volume of new issues (Table 1) and secondary market trading (Table 5)--liquidity has grown substantially. However, formal tests of transaction costs and efficiency of the Euro-bond market have not been reported.

"Excessive" spreads

While transaction costs in the secondary market are not known, the breakdown of primary market gross spreads is widely publicized (see Table 6). As noted, spreads in the Euro-bond market appear high relative to the U.S. domestic market, but moderate relative to foreign markets. The origin of these costs lies in the crucial 
role played by the Continental banks in placing a new issue. Initially, it was essential to have the cooperation of Continental banks in order to guarantee the success of a new issue. To get the full cooperation of distributors, it was necessary to provide compensation at least equal to what they earned on domestic issues. Since sales to individuals predominated, the large selling concessions may have been justified. After large institutional buyers entered the market, the generous spread "became an anachronism," and twotiered pricing resulted. 56

It is difficult to judge where matters stand at the present time. Viendelsohn (1983, p. 16) argues that Continental banks are still the marginal sellers of an issue and, therefore, set the price for services, even though their role in the market is smaller than it was initially. On the other hand, Engel (1983, p. 24) claims that "large-scale placing at about the same price level throughout the market" is characteristic of current practice. The issue of uniform primary market pricing is important since it affects our assessment of conflicts of interest, as discussed below.

The notion of "excessive" spreads might also be interpreted to mean excessive relative to the underwritng risks incurred. We have already noted the asymmetric structure of fees earned by syndicate members. Those in the selling group earn very little, but this seems comensurate with the risks involved. A member of the selling group holds no underwriting risk; he need request bonds only if he has a buyer. He might request more bonds than he knows he can sell (a) if he wants to appear like a larger force in the market and improve his image, or (b) if the manager is likely to allot him only a fraction of his request. In either case, he will have unsold bonds that can be dumped anonymously in the grey market. Managers, on the other hand, bear true underwriting risk, but Mendelsohn (1983, p.15) argues that the risk is "significantly small", since "issues are largely circled before the underwriting 
agreements are signed, and...in most instances the circling commitment is honored." This observation seems consistent with the less disciplined syndicate crganization and the reluctance of managers to pursue syndicate members for excess underwiting costs. If profits were more scarce and less certain, organizational arrangements would change.

Managers feel (relatively) secure with their risks because new issues are largely circled. Issuers feel secure because they can compete among lead managers for the best terms and the best services. The members of the selling group generally feel secure with their positions because allocations can be sold forward in the grey market. This leaves only the buyers to protect their interests, and these as noted, are dominated by large players.

\section{Conflicts of Interest}

Conflicts of interest in the Euro-bond market do not seem to pose serious problems even in the absence of external regulation. 57 The primary conflict of interest cited in the literature is for Continertal banks, which simultaneously underwrite new issues and carry respcnsibility for individual investment funds. It is claimed that the placing power of many Continental banks comes precisely from

their ability to sell new issues to relatively passive clients. In addition to the question whether the Continental bank can perform unbiased investment analysis for their investment accounts, is the issue of two-tier pricing. Continental banks with a vested interest in underwriting the new issue are presumed to buy at par (retail) rather than passing along any institutional aiscounts, or discounts that might be apparent from grey market prices prior to the formal issue date. The investment managers under such conditions hardly 
perform a "best-efforts" service on behalf of their clients.

Sales of this nature, from bank underwriting department to investment clients, are not allowed under U.S. regulations. And disclosure of transactions and grey market prices would allow individuals to monitor the performance of their portfolios.

Sti11, if owners of individual investment accounts are being "stuffed", why don't they move their accounts elsewhere? The answer is that individual trusts receive the tremendous tax advantage of bearer bonds and no taxes withheld on interest, which more than offsets the extra $1 \%$ or $2 \%$ they may have paid on issue, and the fact that a few bonds of questionable quality may have crept into the portfolio. It is a reasonable bargain for all the participants to have struck. The real problem is the limited extent of price competition in the supply of "secrecy services"--it appears that individual account holders must sacrifice some performance to obtain secrecy.

The Grey inarket

The grey market, or pre-market, was originally perceived as a threat to an orderly primary Euro-bond market with uniform pricing. The grey market made it easier for members of the selling group to break ranks with the syndicate and dump their allocations early-actually, to sell them today for future delivery.

In the short run, it is not clear whether the grey market helped to fragment pricing further, or simply brought under public scrutiny the extent of weakness in any new issue. Over the longer run, it is clear that the second effect has dominated. The grey market is credited with helping to increase the liquidity of the 
primary market. It also offers new information to syndicate managers by indicating the market's response to a new issue. If lead managers were to distribute underwriting losses across the syndicate, the grey market price would provide a useful reference point. By increasing liquidity and providing information, the grey market decreases the chance for issue mispricing and increases the chance for a successful offering. The grey market could also supply a reference point for individual investors to evaluate the performance of investment managers. As such, it potentially reduces the practice of "stuffing" individual investment accounts, as noted above.

\section{Effectiveness of the Self-Regulatory Organization}

Although the Euro-bond market operates with minimal government regulation, participants in the market have found it in their interest to establish a self-regulatory body. The Association of International Bond Dealers (AIBD) fills this role. AIBD was founded in 1969 under Swiss law and is based in Zürich. ${ }^{60}$ Nembership is nearly 600, and includes all the major financial institutions active in either primary or seconcary markets. The Board of AIBD has created several subcommittees to study general areas of concern such as education, settlements, market practices and so forth. The Association holds an annual meeting each April to consider specific proposals.

Mendelsohn (1983, p. 14) asserts that AIBD's major role has been in secondary market trading, and that the Association's authority is not accepted concerning primary market practices. Even though most Euro-bonds are exchange-listed, most secondary market trading takes place over-the-counter through market-makers recognized by 
AIBD. $^{61}$ In the primary market, there is no way to recognize a bona fide member of the brokerage community entitled to selling reallowance (i.e., wholesale price reduction). Consequently, price cutting in the primary market depends on individual market power.

Complaints by underwriters concerning primary market practices have been a regular theme of trade publications. ${ }^{62}$ Smaller firms complain of being stuck with mispriced issues, and being left out when quality paper comes to the market. The larger firms point out their discipline problems, and the difficulties of stabilizing a price when small underwriters dump in the grey market. Although the Association's Primary ivarket Committee has discussed the mispricing of new issues and related problems, the debate has never been in public at an annual meeting. As noted earlier, the refusal rate among underwriters has risen, and the spread of new issue prices has converged so that, to some extent, these primary market problems have been self-correcting.

For its part, AIBD prefers to deal with technical issues-Euro-bond settlements, a specialized calculator for Euro-bond dealers, a standardized form for all bonds--and it appears to be fairly successful in these pursuits. 63 It has left insoluble problems (such as trying to enforce a code or realistic new issue pricirg) to be worked out by the market. AIBD does not possess any statutory powers, and so it must operate on consensus. The membership recognizes the need for self-regulation (to promote investor confidence and demand). but also realizes that freedom from regulatory constraints has contributed enormously to the growth and success of the market. Given this history, it seems that $A I B D$ will seek market solutions to problems 
rather than attempting to impose rules of behavior.

\section{Distinguish Micro Problems from Macro Problems}

In 1982. 780 new Euro-bond issues were launched, raising over $\$ 50$ billion. Secondary market trading volume surpassed $\$ 800$ billion. Given these orders of magnitude and the volatility of exchange rates and interest rates, it seems unlikely that all transactions could have been executed without problems, or that there were no frictions between competing parties. However, it is important to differentiate between problems that affect a single issue, an individual firm, or a particular time period, and problems that are life-threatening to the Euro-bond market as a whole and to its constituent institutions.

Trade publications delight in describing broken deals, perhaps more so than smashing successes. 64 The chance of launching an issue when interest rates or exchange rates change suddenly, or trying an innovative issuing approach (e.g., the zero-coupon Euro-bond) that suddenly loses market favor is an integral part of the underwriting risk. 65 Naturally, mistakes of this sort (and underwriting losses) occur, but the market appears to learn quickly and to respond rationally. Activity dries up and maturities shorten in response to interest rate volatility. Firms seek other innovations (e.g., Floating Rate Notes), or return to traditional straight debt depending on demand conditions in the market. 66

To a great extent, then, micro problems (i.e. problems of individual issues, firms, or time periods) appear to have been selfcorrecting in the Euro-bond market without threatening its overall 
integrity. Operating in the absence of statutory regulation is not a license for stupidity--it is almost the contrary. Underwriters who make mistakes must either learn from experience or leave the market. Problems of excess competition and mispricing appear to have been attenuated by members of selling groups learning to refuse bad deals, and by a grey market that sends an early warning to lead managers.

Large borrowers appear to be well-treated in the Euro-bond market. They have shown a propensity to switch lead managers and to shop for the best deal. Large investors and institutions also have the skill to spot mispriced deals, and the power to extract fair pricing. Only the "small" investor, whose funds are managed by some Continental banks appears to be at a perpetual disadvantage. This problem could be reduced if investment managers were required to perform best-effort transactions (as in the U.S., at arm's length from the underwriting department) on behalf of their clients. Considering the tax advantages captured by these "small" investors, their "revealed preference" to incur these costs for the benefit of secrecy may in fact suit their individual needs.

\section{Scope for Increasing Competition in U.S. Investment Banking}

The first four sections of this paper analyzed the operations of the Euro-bond market. Competition among managers and underwriters is virtually unrestrained in the U.S. dollar and Canadian dollar segment of this market. Proposals to increase competition in U.S. investment banking would repeal the Glass Steagall Act and permit 
separately capitalized securities affiliates of U.S. commercial banks to perform the full range of investment banking services for corporations and municipalities. ${ }^{67}$ This is currently the case in most of the world's major developed countries.

Our purpose in this section is first to review the experience with combined commercial and investment banking in the rest of the world, and to draw lessons concerning conflicts of interest, operational efficiency, and related issues. We then combine these findings with our analysis of the Euro-bond market to assess the chances for a favorable transplant of competitive Euro-bond underwriting practices into the U.S. domestic market.

\section{Permissible Bank Activities Worldwide}

An overview of permissible banking activities across countries is presented in Table 11. Among these countries, only Canada and Japan have regulations similar to the United States that prohibit the combination of commercial banking and investment banking activities. Dale (1982, p. 42) notes that in Japan the U.S.-style separation of commercial and investment banking "is regarded as an historical accident rather than a prudential necessity". Table 11 suggests that banks outside the United States have the right to engage in a wider range of activities, including life insurance, equity participations in non-banking firms and security market transactions. An extreme example is in Germany, where the banking act grants a monopoly for all securities brokerage business to banks. 68

The relationship between the nature of the banking system and the degree of competition or macroeconomic control is complex. Japan 


\section{TABLE 11}

\section{INTERNATIONAI COMPARISON OF \\ PERMISSIBIE BUSINESS ACTIVITIES \\ FOR DEPOSIT - TAKING BANKS}

1. UNITED STATES Commercial Banks not allowed to underwrite corporate securities or municipal revenue bonds. They may underwrite general obligation bonds and arrange private placements. Restrictions on interstate banking and non-bank activities.

2. BEIGIUM Banks may hold equity shares in connection with their underwriting activity.

3. CANADA Insurance, fiduciary and underwriting activities not allowed.

Banks cannot own more than $10 \%$ of shares in a non-bank company.

4. FRANCE Underwriting allowed. Deposit banks may hold up to $20 \%$ of shares in a non-bank company. Investment banks may hold up to $100 \%$ of shares in a non-bank company, only financed by deposits greater than or equal to two years maturity.

5. GERIVANY Universal banking, banks engage in all financial activities.

Eanks hold a legal monopoly on all securities brokerage activities.

6. HONG KONG Underwriting allowed. Banks cannot hold more than $25 \%$ of their capital in non-bank company shares. 
TABLE 11 (continued)

7. ITALY

8. JAPAN

9. LUXEMBOURG

10. NETHERLANDS

11. SINGAPORE

12. SWITZERLAND

Underwriting allowed. Banks cannot hold more than $2 \%$ of the ir capital in non-bank company shares.

American pattern.

Underwriting prohibited excert for public sector bonds and by bank overseas subsidiaries.

No statutory restrictions

Underwriting allowed.

No direct restrictions on bank activities.

Equity participations greater than $5 \%$ are subject to approval.

No separation of commercial and investment banking. Banks cannot hold more than $25 \%$ of their capital in non-bank company shares.

Universal banking.

No formal restrictions on banks.

13. UNITED KINGDOM No specific controls.

All activities allowed subject to capital adequacy constraints.

By tradition, a separation between deposit taking banks (i.e. accepting houses) and merchant banks (i.e. issuing houses).

Source: Richard Dale, "Bank Supervision Around the World", New York: Group of 30, 1982.

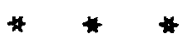


TABLE 12

INTERNATIONAL COMPARISON OF

NIARKET SHARES OF MAJOR BANKS

Percentage of liabilities of:

$\begin{array}{lll}\begin{array}{lll}\text { Commercial } \\ \text { banks }\end{array} & \begin{array}{l}\text { Deposit- } \\ \text { taking } \\ \text { institutions }\end{array} & \begin{array}{l}\text { All } \\ \text { financial } \\ \text { institutions }\end{array} \\ 51 & 13 & 11 \\ 61 & 25 & 18 \\ 43 & 23 & 19 \\ 80 & 35 & 15 \\ 77 & 32 & 17 \\ 87 & 51 & 24 \\ 61 & 30 & 21 \\ 43 & 27 & 15 \\ 68 & 38 & 20\end{array}$

(1) Based on group figures.

The banks included are as follows:

Germany: Deutsche Bank, Dresdner Eank, Commerzbank:

France: Banque Nationale de Paris, Credit Lyonnais, Societe Generale:

Italy:

Banca Nazionale del Lavoro. Banca Commerciale Italiana. Credito Italiano, Banco di Roma, Banco di Napoli;

Netherlands: Algemene Bank Nederland. Amsterdam-Rotterdam Bank, Nederlandsche Middenstandsbank;

Switzerland: Swiss Bank Corporation, Union Bank of Switzerland, Swiss Credit Bank:

Sweden: PK Banken, Svenska Handelsbanken, Skandinaviska Enskilda Banken, Gotabanken

Source: "Wilson Report". (1980, p. 351). 
emulates the U.S. style of separation between commercial and investment banking, yet official guidance is used heavily to effect interest rates and credit allocation. ${ }^{69}$ European banks, on the other hand, allow banks to compete with each other and to offer the widest possible variety of financial services. Yet, as Table 12 illustrates, the concentration of commercial banking activities is much higher in Europe than in the United States. 70

Factors in the U.S. favoring a Successful Adaptation of Competitive Euro-bond Fractices

We now turn to consider those factors in the U.S. economy that would either complement the positive features of the Euro-bond market or offset the negative features described earlier. For the sake of this exercise, we assume that concentration (and returns) in the U.S. investment banking industry are currently high relative to a fully competitive industry (see accompanying paper by Pugel and White). Regulation has prohibited one natural group of competitors (commercial banks) from entering the market. High economic costs have restricted new competition from the United States and abroad from entering the market and reducing concentration.

The Euro-bond market is close to a textbook example of a purely competitive market. ${ }^{1}$ As such, it is not difficult to enumerate the key features that contributed to the growth and stability of that market: 72

1) Financial expertise: skilled people to establish realistic offering prices, adjust for changing market conditions. innovate new products, and contain risks.

2) Techniques for risk management: Fcrmation of large syndicates, well-known issuers, forward sales in the grey market. yield pricing. 
3) Hiarketing expertise: Knowledge of borrower and investor preferences concerning issue costs, information disclosure, tax benefits, and so forth; access to an effective distribution system.

4) Communications technology: Reuters monitor; Euroclear and Cedel for clearing transactions.

5) Liquid secondary markets: To promote primary market demand.

6) Financial capital: To absorb temporary losses.

We assert without formal proof that these features of the Euro-bond market are also characteristic of U.S. financial markets and U.S. commercial banks. By analogy, if U.S. investment banking activities were left open to free competition, the level of financial expertise, risk management skills, and communications technology is such to encourage a stable supply of investment banking services at competitive rates.

Our review also noted several negative factors about the Euro-bond market and the operation of commercial bank affiliates in that market. Might similar negative features also become part of a U.S. banking system if free competition in corporate financial services were permitted?

1) Conflict of Interest. One potential conflict involves Continental banks and their roles as part of the underwriting group and as managers of investment funds. The suggestion in the literature is that excess underwriting fees or unealistic prices have been passed along to unsuspecting, usually passive, trust accounts. In contrast, "self-dealing" is now prohibited under U.S. regulations and applies to subsidiaries as well as affiliates. 73 Another conflict arises between banks and corporate borrowers. 
European practice of combined commercial and investment banking has been associated with relatively close and exclusive ties between banks and non-financial corporations. One fear is that the banks might refuse to provide certain commercial banking services (e.g., loans, lines of credit, foreign exchange) to a corporation unless the bank also provides investment banking services. In the United States, such "tie-in" sales are in restraint of competition and prohibited by the sherman Act. ${ }^{74}$ A related fear is that closer bank/corporate ties might reduce the bank's ability to prepare unbiased loan appraisals or increase the chances for unsound lending. This abuse is a theoretical possibility but highly remote given that imprudent lending could be detected by bank examiners and subject the bank and its management to regulatory sanctions and civil liability. 75

2) Concentration in Banking. The data suggest that banking concentration is substantially higher abroad than in the United States. However Japan, which does have a U.S.-style separation of commercial and investment banking, also shows higher concentration. The United States currently has more than 14,000 commercial banks. Even if interstate banking is permitted and a wave of mergers follows, the Sherman Act could be used to preclude anti-competitive mergers in either commercial or investment banking activities.

3) Macroeconomic Regulation. We have pointed out that macroeconomic regulation in countries with combined commercial and investment banking often takes shape through controls on the amount 
and distribution of credit. These measures would be contrary to a free market for credit. We have argued that these macroeconomic policies are more characteristic of small open economies with a tradition of strong central direction. It is highly remote that the United States would tend toward more centralized control over credit, even if it were easier to implement under a more integrated banking system.

Factors Favoring a less Successful Adaptation and/or Small Gains from Competitive Euro-bond Practices

Markets may establish efficient pricing through competition from either the supply or the demand side. Traditionally, one thinks of competition among suppliers to provide services at the lowest possible prices to capture market share. The result is that all buyers, even those who are completely uninformed about the market, pay the same, fair price for services. On the other hand, one can imagine competition from the demand side to pressure a group of oligopolistic suppliers. Well-informed buyers, who know the fair price for services, may withhold demand, seek close substitutes (bank loans, commercial paper, auction issues) and otherwise pressure suppliers to offer services at a fair price. Eventually, virtually any cartel will break and fair prices will result.

In the U.S. investment banking industry, the statistics on concentration do not reveal much variation. If anything, concentration has tended to increase in the 1970s. However, Hayes, Spence and Marks (1983, p. 79) conclude that the concentration data is deceptive because the market is actually composed 
of distinct segments "within which substantial competition takes place but between which competition may be less robust."

On the demand side, market observers describe a kind of "in-house" competition that has developed in the last 20 years. 76 Historically, corporate financial officers relied heavily on their investment bankers for expertise. Over the years, the quality of financial staff resources of major U.S. corporations has grown substantially. Consequently, firms are more capable of distinguishing the value of alternative investment banking services, and to judge which are cost-effective. In some cases, clients have turned to alternatives that avoid the use of investment banking services altogether. ${ }^{77}$ SEC Rule 415 on shelf registration ought to allow corporations additional time to shop for the best deal.

Large corporations can also turn to the Euro-bond market for active competition if they feel that the domestic market conditions are not sufficiently competitive, as U.S. corporations are increasingly prepared to do. ${ }^{78}$ The initial attraction is the lower cost of offshore funding, but corporations often enjoy secondary benefits in having their underwriting business sought by more competitors. Jnfortunately, the Euro-bond market alternative is available primarily to larger firms. 79

There is reason to believe that the larger, well-informed U.S. corporations have already inspired a highly competitive atmosphere in U.S. investment banking. By actively comparing Euro-bond and U.S. domestic bond issues, U.S. corporations may be "arbitraging" these differences and forcing the price of U.S. investment banking services to competitive levels. It is not clear whether small 
corporations, without access to the Euro-bond market, also receive competitive prices for securities underwriting services. Accepting this argument, efficiency gains from allowing further competition in U.S. investment banking would be relatively small.

\section{Summary and Conclusions}

At the start of this paper, we observed that the market for investment banking services in the United States is not freely competitive because the Glass-Stegall Act excludes one major group of competitors (securities affiliates of commercial banks) from the market. As a result, agents that provide both commercial and investment banking services do not exist in the United States. The Euro-bond market offers an opportunity to examine the operation of a market in which there are few official regulations and no restrictions on who may provide securities underwriting services. The behavior of foreign banks that combine commercial and investment banking was analyzed through their operations in the Euro-bond market and in their onshore activities.

Data on the Euro-bond market were presented to describe the dimensions and competitive efficiency of the market. By all standard measures--new issue volume, secondary market volume, default rate on bonds, underwriting concentration ratios--the Eurobond market must be labelled a success. Without official guidance or subsidy, it has grown a size essentially equal to the U.S. domestic bond market. Adaptation and innovation--syndicate organization, the grey market, automated clearing, and so forth--have accompanied growth. To some extent, individual underwriting 
successes may hate been the result of exogenous events (e.g., exchange, rate changes that effected the supply of DN bonds always lead by German banks) or the beneficial impact that financial secrecy may have on placing power (in the case of Swiss banks). Overall, however, competitive conditions have seemed to stabilize the market--with the availability and terms for funds responsive to market conditions and the more efficient and innovative firms-including affiliates of U.S. commercial banks--capturing market share. Firms in the market have behaved prudently and did not use the absence of regulation as an opportunity for taking excessive risks.

In our review of European banking practices a number of areas for concern were highlighted, including conflict of interest between investment and underwriting activities, excessive linkages between banks and corporations, and concentration in banking activities. We pointed out that U.S. regulations pertaining to disclosure, fiduciary responsibility, anti-competitive practices and the like would prevent similar developments in the U.S. market. The tendency for official guidance in many foreign credit markets, we argued, has little to do with the fact that we find combined commercial and investment banking in these countries.

The paper has documented one case in which a largely unregulated financial market produced very favorable results. Existing U.S. regulation seems capable of dealing with known abuses and points of concern about the linkage of commercial and investment banking activities. The decision to abolish Glass-steagall restrictions could be framed in terms of cost/benefit analysis. The costs are 
the increased risk to the banking system via bank/corporation, bank/trustee, bank/depositor relations. From the Euro-bond market experience, the risks appear small and manageable. The benefits result from increased competition in the supply of investment banking services. Given the power of large corporations and their access to a competitive Euro-market, the benefits of increased competition may be small for this group. However, allowing increased domestic competition would make these benefits more certain and expand their availability to all firms. 


\section{FOOTNOTES}

1. The distinction between the Euro-bond market and foreign securities markets is discussed in Section II.

2. Most OECD countries do not formally separate commercial and investment banking and, as we will describe, some countries permit banks to engage in essentially any activity (i.e. universal or multi-purpose banking) including substantial equity positions in non-financial companies. However, the few exceptions -- the United States, Canada, Japan and perhaps the United Kingdom, where precedent separates commercial and investment banking -- comprise the three largest financial markets in the world. See Richard Dale, Bank Supervision Around the World, (New York: Group of Thirty), 1982.

3. In some sense, question two probes into the macroeconomic costs and benefits associated with el iminating the separaration of commercial and investment banking. Our research design might propose to compare the macroeconomic performance of industrial countries in which commercial banking and investment banking are formally separated with those in which the activities are combined. Macroeconomic performance varies considerably across countries and undoubtedly, regulations affecting the financial sector and the institutional structure of banking play a role. However, macroeconomic performance is a function of many variables and without a highly detailed model it is impossible to determine how great that role is.

4. Mendelsohn (1983, p.5) makes the argument that the thrust of regulation in the United States is disclosure while in Europe, regulation is directed toward resource allocation, national planning and monetary control. Consequently, U.S. authorities for the most part impose no restrictions on issue volume as long as the appropriate disclosure is made. European authorities frequently establish a queue for new issues which is managed to prevent market "congestion" or to achieve interest rate or exchange rate targets. One could argue that these regulatory objectives play the dominant role in European capital markets rather than the coincidence of commercial and investment banking. For more on the regulation of security markets in Europe, see Wymeersch (1983).

5. Throughout this paper we assume that existing U.S. regulations concerning information disclosure, anti-competitive behavior and anti-competitive mergers would apply, even if the Glass-Steagall act were abolished.

6. While it would be interesting to document the innovations in the Euro-bond market made by U.S. commercial bank affiliates, it is beyond the scope of this paper to do so. Our purpose is to shed light on the behavior and characteristics of an unregulated financial market rather that specific individuals within that market.

7. If existing restrictions on interstate branching were maintained, the ability of securities affiliates of U.S. commercial banks to place securities across state lines might be questioned. For our analysis, we assume that such restrictions would not apply to securities affiliates and that they would be permitted to compete on equal terms with existing investment banking houses.

8. Croussement (1981) states that the first Euro-bond issue was in 1961 for the Portuguese oil company SACOR in the amount of 5,000,000 European Units of Account. 
9. World Financial Markets, Morgan Guaranty Trust Company, New York, November 1983. Total volume in the first 10 months of 1983was down 7\% from 1982. See Carl Gewirtz, "Declines in Eurobond Activity Tied to Drop in Dollar Issues, " International Herald Tribune, November 29, 1983a, p. 9.

10. See Gewirtz, ibid., and Weekly Eurobond Guide, Datastream International Iimited, London, various issues.

11. These are gross new issues, without netting out security redemptions. See Financial Statistics Monthly, OECD, November 1983, p. 14.

12. Mendelsohn (1983, p. 10).

13. After January 1, 1983, new federal regulations require U.S. citizens to hold Eurobonds in registered form. U.S. investors must elect registered form as an option, even though the bulk of Eurobond. issues will remain in bearer form. See Read (1983) for further details.

14. Mendelsohn (1983, p. 10) and Magraw (1983, p. 3).

15. Fisher (1981, p. 95), and Mendelsohn (1983, p. 7).

16. In the United Kingdom, the Bank of England controls the queue: In west Germany the Federal Department of Commerce is in charge of domestic issues. In France, new issues must be cleared with the Treasury. And in Switzerland there is an official Issues Committee. See Maycock (1983, p. 5), Dufey and Krishnan (1983, p. 14), Aftalion and Bompaire (1983, p. 3), and Corti (1983, p. 39).

17. Van Agtmael (1983, p. 5) notes, we believe incorrectly, that no queuing exists in the Eurobond market. Compare Fisher (1981, p. 20).

18. See Mendelsohn (1983, p. 10), Dufey and Krishnan (1983, p. 15), Corti (1983, p. 3) and Wymeersch (1983).

19. A bought deal is a pre-underwritten issue, offered to a borrower on a take-it-or-leave-it basis, which is valid for a specified short time period. Bought deals have been offered and closed out within 24 hours. See Fisher (1981, p. 83), and Shirreff (1981, p. 31).

20. For the view that Eurobond selling concessions are relatively high, see Fisher (1981, p. 81), Mendelsohn (1980, p. 184) and Mendelsohn (1983, pp. 13-19).

21. The differential has reached 100 basis points or higher for some issuers. See Karp (1982) and Mendel sohn (1983).

22. Mendelsohn (1980, p.136) citing World Bank records. 
23. Fisher (1981, p. 19).

24. Mendelsohn (1983, p. 5).

25. Mendelsohn (1983, p. 5).

26. Fisher (1981, p. 19).

27. Mendelsohn (1983, p. 15). The purchase is made by the lead manager as agent for the underwriting syndicate in order to avoid double taxation.

28. Fisher (1981, p. 77) notes that underwriters are rarely mailed copies of the subscription agreement prior to closing and so they must have trust in the management group. See also Mendelsohn (1983, p. 16).

29. Mendelsohn (1980, p. 183).

30. Fisher (1981, p. 80).

31. This is the general view expressed by Fisher (1981, p. 80). In the Deutsche mark segment of the market, the major German issuing banks monitor early trading closely to identify banks that break ranks. See Tim Anderson, "Germany's Exclusive Club," Euromoney, May 1983b, pp. 50-2.

32. Grey market prices first appeared on the Reuters Monitor in August 1982, although telephone prices were circulated earlier. Tim Anderson, "Clearing the Grey Clouds," Euromoney, May 1983a, pp. 26-8, and private interviews.

33. See for example AGEFI International Financial Review, London: AGEFI Press Limited.

34. Large institutions buying for trust accounts need not pass along these gains, a problem we explore in Section IV.

35. In the Eurobond market, there is no Papilsky Rule compelling sellers to charge the same price to all buyers as there is in the U.S. market. See Mendelsohn (1983, p. 16).

36. Fisher (1981, p. 38) notes that estimated ratings based on comparison with similar domesic securities are often reported.

37. Fisher (1981, p. 60).

38. Fisher (1981, p. 81).

39. See Shirreff (1981).

40. See Fisher (1981, pp. 83-6) and Fisher, "Imagination Wins Again," Euromoney, February 1981,pp. 125-8 for details. 
41. In 1980, the principal amount of dollar Floating Rate Notes totalled $\$ 4.0$ billion or $31.5 \%$ of all Eurodollar issues, up from $\$ 1.1$ billion and $12.7 \%$ in 1976. See Fisher (1981, p. 103).

42. At the end of 1980, Euro-clear had 123 shareholders and serviced 1,080 member banks. Cedel had 94 shareholders with 1,050 member banks. Fisher (1981, p. 182).

43. Tim Anderson, "The Growing War Between Cedel and Euroclear," Euromoney, February 1981b, p. 35.

44. Mendelsohn (1980, p. 61) displays a deep reverence for the Eurobond market exclaiming, "It saved the industrialized world from an even deeper recession (in the 1970s) than it actually suffered and allowed many industrial countries to maintain an almost unchecked economic expansion."

45. Nendelsohn (1980, p. 47).

46. Mendelsohn (1983, p.11) cites Fisher (1979) claiming that by mid-1976 there had been 19 defaults totaling more than $\$ 300$ million. A recent case alleges that a trader from Bear, Sterns (New York) and another from Union Bank of Switzerland engaged in fraudulent trading, defrauding both companies of $\$ 8.3$ million. The case raises the issue of whether the incident reflects an isolated case resulting from poor internal controls, or whether the market "s general lack of regulation is at fault. The resolution of this dispute, with its third party implications, is an important challenge for the Association of International Bond Dealers's arbitration procedures. See "Bear-Faced Fraud," The Economist, July 14, 1984, pp. 72-3.

47. See "Are the Eurobond Markets Incestuous?" Euromoney, November 1977 , pp. 46-7.

48. Mendelsohn (1980, pp. 185-190) shows that in a typical Eurobond underwriting $(\$ 45 \mathrm{milli}$ ion for 9 years with spread totaling $2.5 \%$ ), the lead manager and co-managers ( 1.5 any) will claim half of the fees. The underwriting group (about 90 ) would share about $38 \%$ of the fees, and the seliing group (perhaps $100)$ would share about $12 \%$ of the fees. Mendelsohn draws the conclusion that most members of the syndicate do not expect profits from their activity. This, of course, presupposes that the entire issue is sold at the offering price -- i.e., that the full $2 \frac{1}{2} \%$ is earned -- which may well not be true.

49. Koenig (1983b, p. 174).

50. Euromoney, "How the Citicorp Issue Rocked the Euromarkets" November 1977 , p. 14.

51. Tim Anderson, "Optimism Shyly Creeps Back to the Bond Markets," Euromoney. May $1981 \mathrm{c}, \mathrm{p} .46$.

52. Gerard Engel, "Underwriters Need to Know Where They Stand," Euromoney, May 1983, p.:24.

53. Ibid.

54. Koenig, "Why Trading is Fun Again," Institutional Investor, May 1983b, p. 172.

55. Koenig, "The Great Liquidity Debate," Institutional Investor, May 1983a, p. 158-9. 
56. Mendelsohn (1983, p.14)

57. In any market setting, one expects to observe agents taking steps to protect the ir interests -- sellers limit the ir product claims, buyers search out product information, and so forth. As we have noted, participants in the Euro-bond market have likewise developed effective mechanisms to protect themselves from loss.

58. Mendelsohn (1980, p. 174) and Mendelsohn (1983, p. 21).

59. For more on secrecy in banking, see Walter (1983) and Walter (1985).

60. Fisher (1981, pp. 183-4).

61. Mendelsohn (1980, p. 195). See the Week ly Eurobond Guide for a listing of AIBD secondary market makers.

62. See for example, Tim Anderson, "Hambro, Hamburg and the Social Club," Euromoney, May 1981a, pp. 31-3 and Tim Anderson, "Optimism Shyly Creeps Back to the Bond Market," Euromoney, May 1981c, pp. 45-8.

63. See Tim Anderson, "Hambro, Hamburg and the Social Club," Euromoney, May $1981 \mathrm{a}, \mathrm{p} .33$. However, concerning recently alleged fraudu Tent trading (see footnote 46), The Economist (July 14, 1984, p. 72) has commented that "Self-regulation in such a market relies heavily on the probity and vigilance of its members, but when they fail a strong watchdog is needed. The AIBD is neither strong nor a watchdog."

64. See for example, David Sherreff and Sarah Martin, "Milestone Deals in the Euromarkets," Euromoriey, October 1981, pp. 269-75.

65. See Karp (1982, pp. 134-5) for a discussion of how several major underwriting firms were caught in Niay 1982 when expectations of U.S. budget deficit relief led them to believe that interest rates would drop.

66. Floating Rate Notes in the Euromarket have proved to be a major success. Money managers have been drawn to these instruments because of yield (typically the six-month LIBOR rate $\left.+\frac{1}{4} \%\right)$ and liquidity has improved so that the bid-ask spread is only 5 basis points (compared to 25 basis points on the most active fixed-coupon Eurobond). See Carl Gewirtz, "Eurobonds," International Herald Tribune, October 31, 1983a. During 1983, the overwhelming percentage of Eurodollar bonds were reported to be classic straight issues, without sweeteners of any sort. See Carl Gewirtz, "Decline in Eurobond Activity Tied to Drop in Dollar Issues," International Herald Tribune, November 29, $1983 \mathrm{~b}$.

67. "Universal banking" is the term generaliy used, but may be a poor choice since some readers will associate it primarily with German banks which are allowed to perform almost any financial service. For the moment, we ignore the important distinction as to whether the commercial and investment banking activities take place in legally separate subsidiaries of a bank holding company or simply in separate departments of a single bank. 
69. The extent of official guidance has been relaxed recently. See Allen (1983) and Sakakibara (1984).

70. Concentration in the United States may be artificially low because of the ban on interstate banking. But note also that the concentration ratios in Europe represent 3-5 banks.

71. The U.S. and Canadian dollar segments of the market are least subject to governmental regulations. See the discussion in Section II.

72. The U.S. OFDI controls in the 1960s were a key feature that led to the Euro-bond market, while the IET diverted foreign borrowers from the U.S. as well. However, since entry into the Eurobond market was never restricted, we expect to see the elimination of any excess profits that might have arisen from these distortions.

73. See the accompanying paper by Saunders on the conflict of interest question.

74. See the accompanying paper by Pugel and White.

75. This point is developed further the accompanying paper by Saunders.

76. The term is used by Hayes (1979, p. 170).

77. Hayes (1979, p. 156) cites the Exxon "Dutch auctions," corporate dividend reinvestment plans and stock-for-stock corporate mergers as three examples.

78. It appears that large U.S. corporations are monitoring very closely both U.S. and Euro-bond market conditions. Exxon devised an issue which it was prepared to launch in either market. See Karp (1982, p. 135).

79. On February 1, 1984, the Alaska Housing Finance Corporation became the first U.S. State agency to offer securities to the Euromarket. To complete the $\$ 100$ million, 10 -year issue, the agency was required to establish an overseas financing corporation in the Netherlands Antilles. See "Alaska to Offer First Eurobonds," International Herald Tribune, January 11, 1984. 


\section{References}

Aftalion, Florin and Bompaire, Frederick. "France: Banking, Money and Bond Narkets," Section 4.5 in A. George and I. Giddy

(eds.), International Finance Handbook, New York: John Wiley, 1983. .

"Alaska to Offer First Eurobonds." International Herald Tribune, January $11,1984$.

Anderson, Tim. "Hambro, Hamburg and the Social Club," Euromoney, May 1981a, pp. 31-3.

"The Growing War Between Cedel and Euro-clear," Euromoney, May 1981b, pp. 35-42.

"Optimism Shyly Creeps Back to the Bond Market," Euromoney, Niay 1981c, pp. 45-8. pp. 26-?. "Clearing the Grey Clouds," Euromoney, May 1983a, pp. $50-2$. "Germany's Exclusive Club," Euromoney, May 1983b,

"Are the Eurobond Markets Incestuous," Euromoney, November 1977, pp. 46-7.

"Bear-Faced Fraud," The Economist, July 14, 1984, pp. 72-3.

Corti, Mario A. "Switzerland: Banking, Money and Bond Markets," Section 4.6 in A. George and I. Giddy (eds.). International Finance Handbook, New York: John Wiley, 1983.

Coussement, André. "When the Bonds Went Round Luxembourg in a Van," Euromoney, February 1981, pp. 81-3.

Dale, Richard. Bank Supervision Around the World, New York: Group of 30,1982 .

Dufey, Gunter and Krishnan, E. "West Germany: Banking, Money and Bond Markets," Section 4.4 in A. George and I. Giddy (eds.), International Finance Handbook, New York: John Wiley, 1983.

Engel, Gerard. "Underwriters Need to Know Where They Stand," Euromoney, May 1983, pp. 24-6.

Financial Statistics Monthly, Paris: Organization for Economic Cooperation and Development, various issues. 
Fisher, Frederick G. The Eurodollar Bond Market, London: Euromoney Publications, $197 \overline{9}$.

Publications, $i 98 \frac{\text { In }}{1 .}$

International Bonds, London: Euromoney

1981, pp. 125-8.

"Imagination Wins Again," Euromoney, February

Gewirtz, Carl. "Eurobonds," International Herald Tribune, October 31, $1983 a$.

Dollar Issues, " International Herald Tribune, November 29, $1983 \mathrm{~b}$.

Hayes, Samuel I. "The Transformation of Investment Banking," Harvard Business Review, January/February 1979, pp. 153-70.

Hayes, Samuel I., Spence, A. Michael, and Marks, David Van Praag. Competition in the Investment Banking Industry, Cambridge, Viass.: Harvard University Press, 1983.

"How the Citicorp Issue Rocked the Euromarkets," Euromoney, November 1977, pp. 12-9.

Karp, Richard. "How U.S. Companies Are Catching the Eurobond Habit," Institutional Investor, August 1982, pp. 127-35.

Koenig, Peter. "The Great Liquidity Debate," Institutional Investor, Nay 1983a, pp. 153-66.

"Why Trading is Fun Again," Institutional Investor, May 1983b, pp. 171-4.

Magraw, Daniel, "Legal Aspects of International Bonds," Section 5.3 in $A$. George and I. Giddy (eds.), International Finance

Handbook, New York: John Wiley, 1983.

Maycock, James E. "United Kingdom: Banking, Money and Bond Markets," Section 4.3 in A. George and I. Giddy (eds.). International Finance Handbook, New York: John Wiley, 1983.

Mendelsohn, M.S. Money on the Move, New York: McGraw-Hill, 1980. "The Eurobond and Foreign Bond Markets," Section 5.1 in A. George and I. Giddy (eds.), International Finance Handbook, New York: John Wiley, 1983.

Puge1, Thomas A. and White. Lawrence J. "An Analys is of the Competitive Effects of Allowing Commercial Banks to Underwrite Corporate Securities," in this volume. 
Read, Hastings. "The Secondary Market Wrestles with TEFRA," Euromoney, August 1983, p. 54.

Sakakibara, Eisuke. "The Japanese Financial System in Transition," in T. Agmon, R. Hawkins and R. Levich (eds.), The Future of the International Monetary System, (Lexington, Mass.: D.C. Heath,

Saunders, Anthony. "Conflicts of Interest: The Case of Commercial Banks and The ir Corporate Underwriting Affiliates," in this volume.

Shirreff, David. "The Warrior Style of CSFB's Rudloff," Euromoney, December 1981, pp. 24-32.

Shirreff, David and Martin, Sarah. "Milestone Deals in the Euromarkets," Euromoney, October 1981, pp. 269-75.

Van Agtmael, Antione W. "Issuance of Eurobonds: Syndication and Underwriting Techniques and Costs," Section 5.2 in A. George I. Giddy (eds.), International Finance Handbook, New York: John Wiley, 1983.

Walter, Ingo: "Global Players in the Financial Secrecy Game," NYU Business, Vol. 3, No. 2, Fall 1983/Winter 1984, pp. 10-7. Unwin, 1985) forthcoming.

$\frac{\text { Weekly Eurobond Guide, London: Datastream International, various }}{\text { issues. }}$

"Wilson Report". Sir Harold Wilson, Chairman of the Committee to Review the Functioning of Financial Institutions, London: Her Majesty's Stationery Office, June 1980.

World Financial Markets, New York: Morgan Guaranty Trust Company, various issues.

Wymeersch, Eddy. "Securities Markets Regulations in Europe," Section 6.2 in A. George and I. Giddy (eds.), International Pinance Handbook, New York: John Wiley, 1983. 